\author{
Karadeniz Uluslararası Bilimsel Dergi \\ Volume: 49, Spring-2021, p. (45-73)
}

ISSN: 1308-6200 DOI Number: https://doi.org/10.17498/kdeniz.894033

Research Article

Received: February 9, 2021 | Accepted: Mar 14, 2021

This article was checked by Dupli Checker.

\title{
ARDAHAN'IN GÖLE İLÇESİNDEKİ DEMİR ÇAĞI SAVUNMA YAPILARI
}

\section{IRON AGE DEFENSIVE STRUCTURES IN ARDAHAN'S GÖLE DISTRICT}

\section{ОБОРОННЫЕ СООРУЖЕНИЯ ЖЕЛЕЗНОГО ВЕКА ГЁЛЕЙССКОГО РАЙОНА АРДАХАНСКОЙ ПРОВИНЦИИ}

\section{Zekeriye AKKURT ${ }^{*}$ Sami PATACI**}

\section{ÖZ}

Bu makalede Ardahan ili, Göle İlçesi'nin; coğrafyası, araştırma tarihçesi, adının kökeni ve ayrıca 1995-1997 ile 2016-2018 yılları arasında, bölgede gerçekleştirilen yüzey araştırmaları sırasında tespit edilen Demir Çağı savunma yapıları ele alınmıştır. Göle, bulunduğu konum itibarıyla Kuzeydoğu Anadolu'nun yüksek dağları ile çevrili olup; bu nedenle yerleşim alanı, bağlı olduğu il merkezine göre daha yüksekte ve soğuk bir iklim tipine sahiptir. Bölgedeki ilk araştırmalar; 20. yüzyıl başlarında gerçekleştirilmiş ve bu çalışmalar, Ortaçağ’a ait kalıntılar üzerine yoğunlaşmıştır. Eskiçağ adına yapılan yüzey araştırmaları ise 1995-97 yıllarında başlamış̦tır. Göle'de gerçekleştirilen bu yüzey araştırmaları ile Kuzeydoğu Anadolu bölgesinin Demir Çağı'nın daha iyi anlaşılması kolaylaştıracak yeni veriler ortaya çıkmıştır. Aynı zamanda bu yeni veriler Doğu Anadolu'da Orta Demir Çağı'nın önemli uygarlığı olan Urartu Krallığı'na ait çivi yazılı metinlerde yer alan bölge isimleri ile Göle'nin isim kökeni hakkında bir takım bağlantıların kurulmasına olanak sunmuştur. Göle, Ortaçağ’da Hristiyan kültürlerce ve Türk fetihlerinin ardından Osmanlı İmparatorluğu Döneminde ceșitli isimler ile anılmıștır. Bölgede gerçekleştirilen son yüzey araştırmaları ile Göle'de Demir Çağı savunma mimarisinin ve çanak-çömlek geleneğinin özelliklerini bünyesinde barındıran arkeolojik alanlar tespit edilmiştir. Bu arkeolojik alanlar, ilçenin: Kayaaltı, Çobanköy, Kuzupınarı, Durucasu, Bellitepe, Balçeşme gibi modern yerleşim yerlerinin yakın çevresinde yer almaktadır.

Anahtar Kelimler: Ardahan, Göle, Demir Çağı, Kale, Gözetleme Kulesi.

\section{ABSTRACT}

* ORCID: 0000-0003-2670-640X, Iğdır Üniversitesi, Lisansüstü Eğitim Enstitüsü, Arkeoloji Anabilim Dalı, Yüksek Lisans Öğrencisi. E-posta: zekiakkurt_@ outlook.com ** ORCID: 0000-0003-1840-6562, Dr. Öğr. Üyesi, Ardahan Üniversitesi, İnsani Bilimler ve Edebiyat Fakültesi, Arkeoloji Bölümü. E-posta: samipataci@ hotmail.com 


\section{Ardahan'ın Göle İlçesindeki Demir Çağı Savunma Yapıları}

In this article, the geography of Göle District, its research history, the origin of its name, and also the Iron Age defensive structures detected during the surveys carried out in the region between 1995-1997 and 2016-2018 were discussed. Göle is surrounded by the high mountains of Northeastern Anatolia due to its location; For this reason, the residential area is higher and has a colder climate than the city center to which it is connected. The first researches in the region were carried out at the beginning of the 20th century and these studies focused on the medieval ruins. Surveys on behalf of antiquity started in 1995-97. Thanks to these surveys carried out in Göle, new data have emerged that will facilitate a better understanding of the Iron Age of the Northeast Anatolia region. At the same time, these new data enabled some connections to be made about the names of the regions in the cuneiform texts belonging to the Urartu Kingdom, which was an important civilization of the Middle Iron Age in Eastern Anatolia, and the name origin of Göle. The lake was called by different names during the Middle Ages, in Christian cultures and after the Turkish conquests during the Ottoman period. Recent research in the region has uncovered archaeological sites in Göle that include features of Iron Age defensive architecture and pottery traditions. These archaeological sites are located in the immediate vicinity of modern settlements such as Kayaaltı, Çobanköy, Kuzupınarı, Durucasu, Bellitepe, Balçeşme.

Key Words: Ardahan, Göle, Iron Age, Castle, Watchtower.

\section{АННОТАЦИЯ}

В нижесдедующей статье, исследуется название района Гёле, Ардаханской провинции, а также оборонительные сооружения железного века того же района, выявленные в ходе исследований в этом регионе в период с 1995-1997 по 2016-2018 годы. Первые исследования в регионе проводились в начале 20 века и были сосредоточены на средневековых руинах. Исследования древнего периода начались в 1995-97 гг. Благодаря исследованиям, проведенным в Гёле, появились новые данные, которые помогут лучше освоить железный век Северо-Восточный регион Анатолии. В то же время они позволили установить некоторые связи между топонимикой региона, в том числе с названием Гёле, с даннымы клинописных текстов, принадлежащих королевству Урарту, которое являлся важной цивилизацией середины железного века в Восточной Анатоли. Гёле называлось разными именами в средние века в христианских культурах и после турецких завоеваний в период Османской империи. В результате последних исследований, проведенных в регионе, были обнаружены археологические памятники в Гёле, которые включают в себя черты оборонной архитектуры железного века и гончарные традиции. Эти археологические памятники расположены в непосредственной близости от современных поселений, таких как Каяалты, Чобанкёй, Кузупинари, Дуруджасу, Беллитепе, Балчешме.

Ключевые слова: Ардахан, Гёле, железный век, замок, сторожевая башня

\section{Giriş}

Kuzeydoğu Anadolu coğrafyasında, tarihi ve arkeolojik araştırmaların çok az yürütüldüğ̈̈ bölgelerin başında kuşkusuz Ardahan ili ve ilçeleri gelmektedir. Bu durumun temel sebepleri arasında genellikle olumsuz iklim şartları ve zorlu arazi yapısı öne çıkmaktadır. Ardahan ili ve ilçeleri çoğunlukla; Kuzeydoğu Anadolu illerini kapsayan bilimsel araştırma projeleri içinde yer alan ve sürekli olarak çok az incelenen bölge konumunda kalmıştır. 
Göle, Ardahan il merkezinin güneyinde yüksek rakımlı bir ovalık arazide yer alan modern bir yerleşim bölgesi olarak varlığını sürdürmektedir. Bölge yer aldığı coğrafya itibari ile Sibirya yüksek basıncının etkisi altında kalarak soğuk bir iklim tipine sahiptir. Bu nedenle bölgede az miktarda tarım arazisi bulunurken, iklimin ve topografyanın etkisi ile bol miktarda oluşan sulak alanlar ve akarsular, ormanlar ve çayır step bitkilerinin yetişmesini sağlarken, diğer yandan geçim ekonomisinin temeli olan hayvancılığın da gelişmesini hızlandırmıştır.

Bölgenin, tarihi ve arkeolojik geçmişi bu güne kadar çok belirli sayıdaki çalışmalar ile anlaşılmaya çalışılmış, ancak bu çalışmalar Göle'nin erken dönemlerinin yeteri kadar anlaşılmasını sağlamamıştır fakat bölge hakkındaki ilk bilgiler, Ortaçağ' da hâkim güç olan Gürcü kültürünün kalıntılarının kaleme alındığı 20. yüzyıl belgelerinden gelmektedir. Göle'nin Eskiçağ dönemleri hakkındaki ilk veriler ise 1990'lı yıllarda gerçekleştirilen yüzey araştırmaları ile anlaşılmaya başlanmıştır. Bu yüzey araştırmaları kısa süreli olup bölgenin erken dönemlerini tam olarak aydınlatmaya yetmemiş, ancak bölge adına yeni bir görüşün ortaya çıkmasını sağlamıştır. Oluşan bu yeni görüş ile Göle adının hem kökeni hem de bu bölgenin en erken tarihinin anlaşılmasına yönelik önemli düşünceler oluşmuştur. $\mathrm{Bu}$ yeni düşüncelerin temelinde ise şüphesiz Van Gölü Havzasında kurulan Urartu Krallı̆̆ının yöneticileri tarafından yaptırılan yazıtlar önemli bir öneme sahiptir. Bu metinlerde geçen bir bölge adı ile benzerlik gösteren Göle kelimesi, bölgenin en erken tarihini anlamamıza yönelik bir takım düşünlerin oluşmasına neden olmuştur. Diğer yandan Göle adı ve bulunduğu coğrafya, Ortaçağ'da Gürcü ve Ermeni Krallıkları ve daha sonra ise Osmanlı İmparatorluğu, döneminde çeşitli isimler ile anılmıştır. Bu nedenle Göle kelimesi, Urartu Krallarının sefer yaptığ 1 bir bölge adı ile benzerlik göstermesi halinde, bölgenin eskiçağ tarihini anlamak adına önemli bilgilerin ortaya çıkmasına yardımcı olabileceği kanaatindeyiz.

Bölgede gerçekleştirilen 2016 ve 2018 y1llarında gerçekleştirilen yüzey araştırmaları ile Göle ilçesinin Eskiçağ adına tespit edilen arkeolojik alanlar çoğunlukla Demir Çağı'na ait nitelikler taşımaktadır. İlçenin modern yerleşim alanlarının yakın çevresinde yer alan bu arkeolojik alanlar, çoğunlukla yüksek noktalarda, su kaynaklarına yakın ve arazi şartlarına göre konumlandırılmıştır. Bu yapılar, kullanım ve inşa tekniklerine göre tarafımızca sınıflandırılarak; Demir Çağı savunma yapılarının özelliklerini yansıtan Kale ve Kule yapıları olarak belirlenmiştir. Ancak bu yapılardan bazıları sadece savunma niteliğinde kullanılmadığı anlaşılmış, yakın çevrelerinde yer alan ve sivil mimari olarak değerlendirdiğimiz yapı kalıntılarından yola çıkarak, bu yapıların hem bir savunma yapısı hem de birer yerleşim yeri özelliği taşıdığı anlaşılmıştır. Dolayısıyla bu makalede, Göle ilçesi sınırlarında yer alan ve Demir Çağı'na tarihlendirilen savunma yapıları; bu çalışmanın ana konusunu oluşturmaktadır.

\section{Konumu ve Coğrafyası}

Göle, kuzeyinde Ardahan'ın merkez ilçesi, güneyinde ve doğusunda Kars ili, kuzeybatısında Artvin, batı ve güneybatısında ise Erzurum ili ile sınır 
komşusudur (Harita 1). (Patacı, 2019: 548). İlçe, 2004-2040 m rakımı ile Ardahan'ın, en yüksek ve yüz ölçümü bakımından en büyük ilçesidir.

İlçenin güneyinde, Allahu Ekber dağları yer alırken, bu dağ kütlelerinin kuzey yamacından kaynaklarını alan Kayınlık, Türkmen ve Kür çayları, Göle Ovası'nın kuzeyinde birleşerek, Kuzeydoğu Anadolu ve Transkafkasya'nın en önemli su kaynağı olan Kura Nehrini oluşturmaktadır (Erginal, 2016:11). Bölge, kuzeyden gelen Sibirya yüksek basınç sisteminin etkisi ile sert karasal iklim tipinin özelliklerini en belirgin şekilde yansıtmaktadır. Kışları soğuk ve sert, yazları ise daha çok yağışlı geçmektedir (Erginal, 2016: 10; Patac1, 2019:548). İklimin ve yüksek topografyanın bir sonucu olarak bölgede, bitki türleri bakımından çeşitlilik görülmektedir. Soğuk iklim koşulları altında yetişebilen sarıçam, bölgenin orman yoğunluğunu oluştururken, aynı zamanda çayır-step bitkileri olarak bilinen ve 2000 m rakımlarda yetişen sup-alpin ve alpin bitkileri de önemli bir yoğunluğa sahiptir (Atalay, Tetik ve Yılmaz, 1985: 63-65; Koçman, 1990: 49-51). Zengin bitki topluluğu ile Göle'de, büyük baş hayvancılığın yanı sıra küçükbaş hayvancılık ve kümes hayvancılığı yoğun olarak yapılırken, son yıllarda bölgede arıcılığın da önemi artmıştır (Patac1, 2019a: 548).

Göle ilçe merkezinin yaklaşık 2004-2040 m rakıma sahip olmasına rağmen, bölgede kısıtlı miktarda tarımsal ürünler yetiştirilmektedir. $\mathrm{Bu}$ ürünler arasında; Buğday, arpa, patates ve yulaf gibi bitkiler üretimde başı çekmektedir (Patac1, 2019a: 548).

\section{Araştırma Tarihçesi}

Göle'deki ilk araştırmalar, 20. yüzyıl başlarında bölgeyi ziyaret eden Gürcü tarihçi Ekvtime Takaishvili tarafından, gerçekleştirilmiştir. Takaishvili, Ortaçağ araştırmaları sırasında, Göle'nin bulunduğu coğrafyaya verilen isim ve bölgede yaşayan halklar hakkında kısa bilgiler vermiştir (Takaishvili, 1991: 8-10). 1977 ve 1998 yılları arasında ise Ardahan adına gerçekleştirilen araştırma projeleri kapsamında, bölgeye gelen yerli ve yabancı bilim insanları Ortaçağ yapıları ile Gürcü ve Ermeni kültürlerini incelemek amacı ile Göle ilçesini de ziyaret etmişlerdir. $\mathrm{Bu}$ araştırma projeleri sırasında, 1977 ve 1983 yıllarında bölgede; Erzurum, Artvin ve Ardahan çevresi Ortaçağ kalıntıları konusunda önemli incelemeler gerçekleştiren R.W. Edwards: Ardahan ve Artvin bölgesindeki Gürcü ve Ermeni kültürlerinin, bölgedeki baskınlığı üzerine araştırmalar gerçekleştirmiştir (Edwards, 1988: 119-141; Patac1, 2016: 31). Edwards, 1983 yılındaki araştırmalarını, Göle ilçesi sınırlarında sürdürerek; Ortaçağ'a tarihlendirilen, savunma ve dini mimariye ait yapılar tespit etmiştir (Edwards, 1988: 122-123). Bölge adına bir diğer Ortaçağ araştırmaları ise 1995 yıllında, M. Kadiroğlu-Leube tarafından başlatılan ve F. Bayram tarafindan tamamlanan, Ortaçağ yüzey araştırmaları projesidir (Kadiroğlu-Leube, Yazar ve Karaca, 1996: 397; Bayram ve Yazar, 2010: 4-5). Kadiroğlu ve ekibi 2000 yılı çalışmalarında, Göle ilçesinde yer alan Ortaçağ Gürcü mimarisi adına, bölgede incelemelerde bulunmuştur (Kadiroğlu-Leube, Yazar ve Karaca, 2001: 93). Göle'de gerçekleştirilen araştırmalar sayesinde bölgenin Ortaçağ'daki genel durumu hakkında önemli 
bilgiler sağlanmıştır; ancak ilçenin Eskiçağ tarihi ve arkeolojik geçmişi adına gerçekleştirilen çalışmalar, Ortaçağ araştırmalarından daha azdır.

Göle'nin, Eskiçağ araştırmaları daha önce de bahsedildiği gibi genellikle, Doğu Anadolu ve Ardahan'da gerçekleştirilen yüzey araştırmaları ile birlikte sürdürülmüştür. Bu bakımdan, bölgedeki ilk Eskiçağ araştırmaları 1995-1997 yılları arasında, K. Köroğlu tarafından Artvin ve Ardahan illeri yüzey araştırmaları projesi ile gerçekleştirilmiştir (Köroğlu, 1996: 376-380; Köroğlu, 1998: 147; Köroğlu, 1999: 127). Köroğlu, Ardahan'ın merkez ilçesi ile Çıldır, Hanak ve Göle ilçelerindeki bazı yerleşim alanları çevresinde araştırmalar yürütmüştür. $\mathrm{Bu}$ incelemeler sırasında, Eskiçağ ve Ortaçağ'a tarihlendirilen kale ve kule kalıntıları, kurganlar, kaya kilisesi ve bir höyük tespit etmiştir (Patac1, 2016: 31). Yüzey araştırma projesinin, Göle bölümünde; ilçenin güneyinde, Erzurum/Şenkaya sınır bölgesinde ve Allahu Ekber Dağ silsilesinin kuzey yamacında yer alan Ogli (Köroğlu) kalesi de incelenmiştir (Köroğlu, 1998: 148: Patac1, 2015; 67-68). Bu yap1, daha önce bölgede Ortaçağ araştırmaları gerçekleştiren Edwards (1988) tarafından da incelenmiş ve Urartu dönemine tarihlendirilmiştir, fakat K. Köroğlu, Ogli kalesinde tekrar incelemelerde bulunmuştur. Köroğlu; bu yapının Urartu krallığı ile doğrudan bağlantı kurabilecek somut kalıntılardan yoksun olduğunu dile getirerek, Ogli (Köroğlu) Kalesi'nin açık bulgular olmadan tarihlendirilmeyeceğini vurgulamıştır (Köroğlu, 1998: 148). Bu araştırmalardan sonra, Göle ilçesinde Eskiçağ Dönemine dair bilimsel çalışmalar, 2016 yılına kadar durmuştur.

Ardahan sınırlarında, 2013-2018 yılları arasında gerçekleştirilen ve bölgenin hem Eskiçağ tarihini hem de Ortaçağ dönemlerini kapsayan yeni bir yüzey araştırması projesi başlatılmıştır. Daha önceki projelerden farklı olarak bu araştırmada sadece Ardahan ili ve ilçeleri konuya dahil edilmiştir. 2016-2018 yıllarındaki araştırma programı ile incelenen Göle ilçesin de hem Eskiçağ hem de Ortaçağ Dönemine ait arkeolojik yapı kalıntıları araştırılmıştır. Bu çalışmalar sırasında, önceki yıllarda bölgede belgelenen arkeolojik alanlar, yeniden değerlendirilmek ve arazideki son durumlarını anlamak için tekrar ziyaret edilmiştir. Yeni çalışmalarla, Tunç ve Demir Çağları ile Ortaçağ'a tarihlendirilen savunma yapıları ve aynı zamanda Ortaçağ dini mimarisi örnekleri tespit edilmiştir. $\mathrm{Bu}$ makalede 2016-2018 yıllarında Göle İlçesinde belgelenen Eskiçağ savunma yapıları üzerinde durulacaktır.

\section{Göle Adının Kökeni}

Günümüzde, Göle kelimesi; Ardahan'ın güneyinde, Erzurum Şenkaya'nın; kuzeydoğu yönünde, Kars İl'inin ise kuzeybatı istikametinde yer alan coğrafyaya verilen isimdir. Bulunduğu coğrafyada, Antik ve Geç Antik Dönem toplumlarının kültürel etkisi altında kalan bölge, farklı uygarlıkların ürettiği çeşitli isimler ile tanınmıştır. Ancak bu adlandırmalar, bölgenin hangi özelliğinden dolayı verildiği çok az bilinmektedir. Coğrafyanın kültürel birikimini ve belki de toponimlere yönelik kanıtları bölgede yaşamış ya da bölgeye farklı amaçlar ile gelmiş halkların geride bıraktıkları maddi kültür kalıntılarından yola çıkarak aramak mümkünse de sistemli arkeolojik kazı çalışmalarının yürütülememiş olması sebebiyle bu konu günümüze değin eksik kalmıştır. 
Urartu krallarının kendi icraatlarını yazdırdıkları yıllıklarda yer alan ülke isimlerinden birinin Göle ve yakın çevresi ile ilişkili olabileceği üzerinde durulmaktadır. Bu nedenle, ülkesinin sınırlarını genişletme amacı güden Urartu kralı II. Sarduri (MÖ 756-730), bu bölgeye gerçekleştirdiği seferler sonunda yazdırdığ 1 icraat yıllıklarında ilk defa 'Qulha' ülkesinden bahsetmiştir. Bu ülke adının, sefer yapılan coğrafyada yeni bir bölge adı olarak anılması, Göle ile terminolojik bir bağlantı kurulabileceğini göstermiş̧tir.

II. Sarduri'nin kuzey seferlerini anlattı̆g 1 ve 'Analıkız' olarak tanımlanan alanda ve daha sonra Surp Pogos Kilisesi duvarına konmuş olan stel üzerindeki yıllıklarda geçen 'Qulha' kelimesinin, Göle ile yakın ilişkili olduğu günümüzde kısmen de olsa kabul görmüştür (Köroğlu, 2001; 726). Nitekim bu konu üzerine detaylı incelemeler gerçekleştiren Kemalettin Köroğlu, Göle ile Qulha kelimeleri arasındaki bağlantıyı açıklamak ve güçlendirmek için öncelikle, bölgeye yapılan seferler sonunda bölgede ve yakın çevresinde tespit edilen çivi yazılı metinlerden ve daha sonra bu seferlerin sonuçlarının anlatıldığı yıllıklarda, adı geçen ülkelerin coğrafyalarından ve ayrıca bu bölgelerden elde edilen ganimetlerin türlerinden yararlanarak bu iki kelimenin paralellikleri üzerinde durmuştur (Köroğlu, 2001: 727). Buna göre; I. Argişti (MÖ 786-764) döneminde Van Gölü Havzası'ndan kuzeye yapılan seferler, II Sarduri döneminde Aras Vadisi'nin kuzeyine ve kuzeydoğusuna kadar genişletildiği anlaşılmıştır (Çilingiroğlu, 1997, 35; Köroğlu, 2001; 722-726). I. Argişti'den (MÖ 786-764) sonra yönetime geçen II. Sarduri (MÖ 764-730) askeri gücünü, babasının belirlediği sefer rotalarında yer alan; Diauehe, iga(ne), Abiliane, Etiune ve Eriahe bölgelerinin üzerine yoğunlaşmıştır (Köroğlu, 2001: 726). Ayrıca bunlara ek olarak II. Sarduri bu seferler sirasinda asıl zaman harcadığı ülke, adı bilinen ülkeler arasında, adı ilk defa bu krala ait yıllıklarda da geçen Qulha ülkesidir. Daha önceki seferler sonunda ele alınan yazıtlarda adı geçmeyen bir bölge olan Qulha, ilk ve son defa II. Sarduri'ye ait olan yazıtlarda bulunmaktadır. Daha önce kuzeye yapılan seferlerin rotaları göz önüne alındığında Qulha Ülkesinin de Aladağların kuzeyinde yer alması muhtemeldir. $\mathrm{Bu}$ durumda Köroğlu tarafindan belirtilen ve önerilen coğrafyanın da bu alanda olması ve Qulha kelimesinin günümüzde Göle ile bağdaştırılması ve Ardahan ovasında bir noktaya yerleştirilmesi, sunulan gerekçeler ile kabul edilebilir bir öneri haline gelmektedir (Köroğlu, 2001: 735-736; Patac1, 2015: 57).

Keza bu konu ile ilgili olarak, 1983 yılında Göle'de araştırma gerçekleştiren Edwards'ın da Qulha ülkesinin Göle olabileceği yönünde bazı ifadeleri bulunmaktadır (Edwards, 1988: 122). Edwards ve Köroğlu'nun üzerinde durduğu konunun açılığa kavuşması ancak bölgede gerçekleştirilecek olan yeni araştırmalar ve arkeolojik kazılar sonunda netlik kazanacağını ummaktayız. Diğer yandan Qulha ülkesi ile bağdaştırılan tek bölgenin Göle olmadığını da belirtmekte yarar vardır. Bu bölge ise MÖ IX. ve VIII. yüzyıllarda ortaya çıkan ve Doğu Karadeniz kıyılarını ve Gürcistan' ın batı topraklarını kapsayan 'Kolkhis' bölgesi ile de (Çiloğlu, 1993: 33-34; Arslan, 2000: 26; Kızgut, 2016: 32-37) terminolojik yönden bir bağ kurulmaya çalışılmaktadır fakat Qulha ülkesi ile Kolkhis bölgesinin 
birbiri ile bağdaştırılmaya çalışılması, Aşağ Çoruh Vadisinde Urartu Krallığının kültürünü yansitacak herhangi bir buluntunun mevcut durumda tespit edilememesi, kurulmaya çalışılan bu bağlantının önüne geçmektedir. Ayrıca Urartu Krallığının Orta Demir Çağ'ındaki askeri teçhizatının da bu bölgenin zorlu coğrafyasını aşacak düzeyde olmaması da Qulha ülkesinin, Kolkhis bölgesi olabileceği yönündeki ihtimali düşürmektedir. Bu nedenle de Qulha ülkesinin; Urartu krallı̆̆ 1 için hem ganimet açısından zengin hem de seferler sırasında askeri ulaşıma daha elverişli bir coğrafyada olması gerektiğini dile getirebiliriz. Bu unsurlar göz önüne alındığında ise bu koşullara uygun bölgenin Göle olması yüksek ihtimaldir (Köroğlu, 2001: 735-737).

Ortaçağ'da Göle, Gürcüler tarafindan kurulan ve MÖ IV. yüzyıldan itibaren Iberia Krallığı sinırları içinde Gürcüce (3mms) 'Kola', Ermenice de ise 'Kol' olarak ifade edilmiştir (Honigman, 1970: 160; Konukçu, 1999: 24-25; Patac1, 2019a: 548). XIX. yüzyılda 'Merdinik' adıyla anılırken bölge, (Konukçu: 1999: 25) Osmanlı kaynaklarında 'Küçük Ardahan' şeklinde isimlendirilmiştir (Kırzıoğlu, 1953: 5). XX. yüzyılın başlarında ise Ardahan'ı ziyaret eden Gürcü tarihçi Ekvtime Takaishvili; Göle (Kola) hakkında bazı bilgilere yer vermiştir. Tarihçinin aktardığına göre; Göle'nin bulunduğu arazi etrafında bulunan dağların yükseltisinin aşağısında kaldığı için ilkbaharda, yoğun yağışların oluşması sonunda artan su miktarı, araziyi bataklığa çevirmesi ile bu coğrafyada yaşayan Tatarlar tarafindan bölgeye 'Göl' anlamına gelen 'Gel' adını verdiklerini ifade etmiştir (Takaishvili, 1938: 8-10). Her ne kadar Eskiçağdan günümüze kadar bölge için kullanılan terimler birbirinden farklı olsa da Göle'nin, bu dönemlerde kültürel çeşitlilik açısından önemli bir noktada yer aldığını dile getirebiliriz.

Eskiçağdan günümüze kadar çeşitli uygarlıkların hâkimiyeti altında kalan Göle, bulunduğu bölgedeki siyasi ve kültürel mücadelenin içinde kalmış ve farklı isimlerle anılarak belgelenmiştir.

\section{Göle'deki Demir Çağı Savunma Yapıları}

Günümüze kadar gerçekleştirilen araştırmaların azlığı Tunç ve Demir Çağları Ardahan'ına ve Göle ilçesine ilişkin bilgilerimizi sınırlı tutmuştur; ancak 2013-2018 yıllarında yoğunlaştırılan araştırmalarda bölgenin Tunç ve Demir Çağlarına ait veriler üzerine olumlu bir ilerleme kaydedilebilmiştir. Özellikle, 2016-2018 yılı araştırmalarında Göle coğrafyasına odaklanılması ile Demir Çağı kültürünün niteliklerine sahip ve savunma yapısı olarak değerlendirilen; beş kale ve beş adet kule yapısı tespit edilmiştir. Buna göre, Ardahan il sınırları içinde Demir Çağı verilerine nazaran Tunç Çağı'na dair verilerinin, il merkezi ve çevresinde yoğunlaştı̆̆ 1 anlaşılırken, son çalışmalar ile Demir Çağı Dönemine ait verilerin daha çok Göle İlçesinde yoğun olduğu anlaşılmıştır.

$\mathrm{Bu}$ araştırmalar sonunda Göle'de, Demir Çă̆g'na tarihlendirilen savunma yapıları arasında; Kayaaltı (Omega) Kalesi, Çobanköy Kalesi ve Yerleşimi, Kuzupınarı Kalesi ve Yerleşimi, Durucasu-Şimşimik Kalesi, Bellitepe Kalesi, Bellitepe-Batı ve Doğu Kuleleri, Balçeşme-Kayınlık Kulesi, Balçeşme-Şipşirik 
Kulesi, Balçeşme-Tekmezar Kulesi ve Yerleşimi gibi arkeolojik alanlar yer almaktadır (Harita 1).

\section{Kayaaltı (Omega) Kalesi}

Kayaaltı Kalesi, Ardahan il merkezinin karayolu ile $21 \mathrm{~km}$ güneyinde, Göle ilçe merkezinin ise yaklaşı 25 km kuzeyinde yer alan Kayaaltı köyünün 1,2 $\mathrm{km}$ batısında yer almaktadır (Harita 1). Kale, yaklaşık $2240 \mathrm{~m}$ bir rakıma sahip, yerli halk tarafından Ziyaret Tepe olarak adlandırılan tepenin zirvesinde Eskiçăg savunma niteliği taşıyan mimari bir yapıdır (Patac1, 2019b: 138). Bu yapı teknik açıdan değerlendirildiğinde; küçük, orta ve fazla büyük olmayan taşlar ile Eskiçăg yapılarında sıklıkla karşılaşılan, kuru duvar tekniği ile oluşturulmuştur. Kayaaltı kalesinin özgün planı, Ardahan il sinırları ve Doğu Anadolu coğrafyasında ender görülen türlerdendir. $\mathrm{Bu}$ nedenle, kalenin doğu yarısını oluşturan duvar, Yunancadaki Omega $(\Omega)$ harfi formunda inşa edildiğinden kalenin mevcut Kayaaltı adının yanı sıra 'Omega' ismi de bu yapı için kullanılmışıtır (Resim 1), kalenin batı yarısı ise yarım yuvarlak bir plana sahiptir (Patac1, 2019b: 138). Bu ünik nitelikli mimari yapının ana duvarları (iç duvarları) kuzey-güney yönünde $72 \mathrm{~m}$; doğu-batı yönünde ise $68 \mathrm{~m}$ ölçülerindedir.

Kale'de ana duvarlar dişında yapıyı dıştan çevreleyen bir duvar kalıntısı daha bulunmaktadır; fakat bu duvar, ana duvarlar ile karşılaştırıldığında arazide daha basit ve dayanıksız bir şekilde inşa edildiği gözlemlenmektedir. Savunma yapısının çevresinde yer alan bu basit duvar örgüsü, kalenin arazi üzerinde kapladığı ölçülere dâhil edildiğinde arkeolojik alanın boyutları, kuzey-güney yönünde $90 \mathrm{~m}$; doğu-batı yönünde ise 98 m'lik ölçülere ulaşmaktadır. Arkeolojik alandaki duvar kalınlıkları 2,10 m ile $3.00 \mathrm{~m}$ arasında değişmektedir; kalede korunan maksimum duvar yükseklikleri 2.20 m'dir. Kale'ye giriş arazi üzerinde tespit edildiği kadarı ile bat1, kuzey ve güney yönlerindeki üç ayrı noktadan sağlandığı anlaşılmaktadır.

Arkeolojik alanın neredeyse merkezinde, işlevi hakkında arkeolojik bir kazı gerçekleşmeden kesin bir karar verilemeyeceği, büyük oranda tahrip olmuş bir yapı kalıntısı tespit edilmiştir. Bu yapının arazide gözlemlendiği kadarı ile normal bir mimari yapıya göre daha küçük ölçülerde olması, bu kalıntının bir mezar olabileceği tarafimızca düşünülmektedir (Patac1, 2019b: 139). Diğer yandan yine kalenin içinde, batı duvarlarının iç kesiminde arazi seviyesinde kalıntılarına rastlanılan, dikdörtgen planlı belli belirsiz bir mekân daha tespit edilmiştir. Bu yapı kalıntısının işlevi hakkında ileri sürülecek olan yorumlar, arazideki yoğun bitki varlı̆ğ ile engellenmektedir. Kalede ve yakın çevresinde yapılan incelemelerde az sayıda obsidyen parçalarına ve Tunç ve Demir Çağlar'ına tarihlenebilecek türden, çanak çömlek buluntuları tespit edilmiştir. İncelenen çanak-çömlekler monokrom, siyah, gri, kahve ve devetüyü renklerde olup tarak ve az sayıda kazıma bezemeli örnekler bulunmaktadır (Resim 2). Arkeolojik alanda Tunç Çağı'na ait çanakçömlek buluntuları daha yoğundur; ancak mimari özelliklerinden yola çıkılarak Demir Çağı'nda da kullanılmaya devam etmiş olması muhtemeldir. 


\section{7. Çobanköy ve Kuzupınarı Kaleleri ile Bellitepe Kuleleri}

Çobanköy ve Kuzupınarı'nda tespit edilmiş kaleler ile Bellitepe'deki Doğu ve Batı kuleleri daha önceki yayınlarda (Patacı, 2019c: 110; Patacı ve Oral Patacı, 2020: 229) detaylı olarak ele alındığından bu makalemizde kısaca değinilmektedir. Çobanköy, Ardahan il merkezinin karayolu ile $50 \mathrm{~km}$ güneydoğusunda, Göle ilçe merkezinin ise $26 \mathrm{~km}$ kuzeydoğusundadır (Harita 1). Arkeolojik alan, Çobanköy yerleşiminin batı kesiminden yaklaşık olarak $700 \mathrm{~m}$ kadar ileride ve bu köyün kuzeybatısında bulunan 2188-2200 m rakıma sahip tepelik alanın, zirvesin de tespit edilmiştir (Patacı ve Oral-Patacı, 2020: 229). Bulunduğu arazi üzerinde iç ve dış surlara sahip bir kale görünümünde olan bu Demir Çağı savunma yapısı ve yerleşimi, arazi üzerinde toplamda 250 x 85 m'lik bir alanı kaplamaktadır (Patacı, 2019b: 139).

Kuzupınarı köyü, Ardahan il merkezinin güneybatısında karayolu ile yaklaşık 45 km'lik bir mesafededir (Patacı ve Oral-Patacı, 2020: 231-232). Kale ve yerleşim alanı, Göle ilçe merkezinin 26.7 km kuzeybatısındaki Kuzupınarı Köyü’nün batısında geniş bir ovaya bakan tepenin doğu ucunda yer almaktadır (Harita 1). 2170-2182 m rakımları arasındaki bu alan 2017 yılında tespit edilmiştir (Patacı ve Oral-Patacı, 2018: 18-19; Patac1, 2019b: 141). Kale ve yerleşim alanı özgün mimarisi ile bulunduğu bölgede ve yakın çevresinde ender plana sahip savunma yapıları arasında yer almaktadır. Kalenin dört kenarındaki yuvarlak planlı burçları, yapıyı diğer Ardahan kalelerinden ayırmaktadır.

Bellitepe-Batı kulesi, Göle ilçesinde yer alan Bellitepe köyünün yaklaşık olarak 600/650 m kadar batısında, Bellitepe ve Yeleçli köylerini birbirine bağlayan karayolunun $160 \mathrm{~m}$ kuzeyindeki fazla yüksek olmayan bir tepenin üzerinde yer almaktadır (Patac1, 2019b:143-145; Patac1 ve Oral-Patac1, 2020: 232-234) (Harita 1). Bu arkeolojik alan 2017 yılı yüzey araştırmaları sırasında tespit edilmiştir (Patac1, 2019b:143). Bunun yanı sıra aynı bölgede; Bellitepe-Batı Kulesi ve Kuzupınarı Kalesi gibi, bir Demir Çağı savunma yapısı daha Bellitepe köyünün 2.2 $\mathrm{km}$ doğusunda, modern karayolunun ise 500 m kuzeyinde, 2129-2138 m rakıml bir tepelik alan üzerinde, tespit edilmiştir ve Bellitepe-Doğu kulesi olarak adlandırılmıştır (Patac1, 2019b: 144; Patacı ve Oral Patacı, 2020: 233-234). Bellitepe Batı ve Doğu olarak ele alınan ve Demir Çağ'ında yer aldığı bölgede hem bir kontrol noktası hem de bir gözetleme yapısı işlevinde kullanılmak amacı ile inşa edildiği düşünülmektedir. Bellitepe Batı Kulesi Kuzupınarı Kalesi gibi dört kenarında yuvarlak planlı burçlara sahiptir.

\section{Durucasu-Şimşimik Kalesi}

Durucasu köyü, Ardahan il merkezinin güneyinde karayolu ile yaklaşık 50 $\mathrm{km}$ mesafededir. Göle ilçe merkezinin ise karayolu ile $11 \mathrm{~km}$ kuzeydoğusunda yer almaktadır (Harita 1) . Bu köyün yaklaşık $1.6 \mathrm{~km}$ batısında, menderes çizerek kuzey-güney istikametinde ilerleyen Şimşimik Deresi'nin 120 m doğusunda, 2018 yılı yüzey araştırmalarında tespit edilen bir kale yapısı bulunmaktadır (Patacı, 2019b: 140; Patac1 ve Altun, 2020: 1866). Kale, ufak boyutlu bir höyük üzerinde yer almaktadır (Resim 3 ). Bu höyüğün zirvesinde, kuzeydoğu-güneybatı 
istikametinde konumlanan kalenin ölçüleri, arazi seviyesinde oldukça kötü durumda korunan duvar kalıntılarından anlaşıldığı kadarı ile yaklaşık 44 x $30 \mathrm{~m}$ boyutlarındadır (Patacı ve Altun, 2020: 1866). Kalenin doğu duvarı diğer yönlerdeki duvar kalıntılarına göre daha iyi korunmuştur.

Yapının hemen güneyindeki alanda ise bazı kaçak kazı çukurları tespit edilmiştir (Resim 4). Bu kaçak kazı çukurlarının birinde bir Demir Çağı mezarının oldukça tahrip edildiği gözlemlenmiştir. Arkeolojik alanda yapılan gözlemler sonunda savunma yapısının güneyindeki alanın mezarlık işlevinde kullanıldığı muhtemeldir (Patacı ve Altun, 2020: 1865). Kalenin yapısal bütünlügüne bakıldığında çoğunlukla orta boylu ve kyklopik olarak tabir edebileceğimiz taşların bir araya getirilmesi ile kuru duvar tekniğinde inşa edildiğini anlaşılmaktadır. Bu alanın muhtemelen Erken Demir Çağ'ında inşa edilmiş olduğu tarafımızca düşünülmektedir. Kale ve çevresinde yapılan incelemelerde herhangi bir küçük buluntu tespit edilememiştir (Patac1, 2019b: 140). Diğer yandan alanın hemen güneyinde, yakın döneme ait olduğunu düşündüğümüz kule biçimli bir kireç pişirme ocağı yer almaktadır.

\section{Bellitepe Kalesi}

Kale; Göle ilçe merkezine karayolu ile $20 \mathrm{~km}$ kuzeybatısında yer alan Bellitepe köyünün, $550 \mathrm{~m}$ kuzeyinde tepelik bir alan üzerinde yer almaktadır (Patacı ve Altun, 2020: 1865). Bellitepe-Kalesi, aslında bölge de gerçekleştirilen 2017 yılı araştırmaları sırasında keşfedilmiş ancak alandaki detaylı incelemeler 2018 yılında gerçekleştirilebilmiştir (Patacı ve Oral Patacı, 2018: 24). Göle sınırların içinde savunma mimarisine verilen önem esasen, bu bölgede tespit edilen savunma yapılarından da anlaşılmaktadır. Kuzupınarı ve Bellitepe köylerinin sınırları boyunca, doğu-batı istikametinde belirli aralıklar ile konumlanan iki kale ve iki kulenin yer alması, bölgede bu savunma yapılarının bulunmasının rastlantı olamayacak kadar stratejik bir öneme sahip olduğunu göstermektedir (Harita 1). Bu nedenle, bu bölgede mutlaka çok daha kapsamlı arkeolojik çalışmaların yapılmasını gerekmektedir (Patac1, 2019b: 145; Patac1 ve Altun, 2020: 1865).

Bellitepe Kalesi, 2214 m rakımda bir tepenin zirvesinde inşa edilmiş kare

planlı Eskiçağ savunma yapısıdır (Resim 5). Yap1, kuzeydoğu-güneybatı doğrultusunda konumlanmakta ve 55 x $53 \mathrm{~m}$ boyutlarındadır. Kalenin mimarisi teknik açıdan incelendiğinde, Göle ilçesi sınırlarında tespit edilen diğer savunma yapıları ile benzer özellikler taşımaktadır (Patac1, 2019b: 145). Orta ve küçük boyutlu taşlar ile kuru duvar tekniğinde inşa edilen yapının duvarları maksimum 1.10 m yükseklikte korunabilmiştir (Resim 6). Duvar kalınlıkları yer yer 2.10 m ilâ $2.36 \mathrm{~m}$ arasında değişmektedir (Patacı ve Altun, 2020: 1865). Kalenin ana duvarları dışında, yapının özellikle kuzey duvarının $10 \mathrm{~m}$ kadar ilerisinde çevre duvarı niteliği taşıyan kalıntı gözlemlenmiştir (Patacı, 2019b: 146). Savunma yapısının, doğu kenarının dışındaki arazide ise farklı mimari yapılara ait temel seviyesinde korunmuş izler tespit edilmiştir fakat bu nokta oldukça tahrip olmuş durumdadır. Ayrıca, kalenin hem içinde hem de güneyindeki arazide yine arazi seviyesinde korunmuş olan kare ve dikdörtgen planlı yapılara rastlanılmıştır; ancak 
bu yapılar oldukça kötü korunduğu için bu yapılar hakkında bir yorum yapabilmek şu an için mümkün gözükmemektedir. Belki de tıpkı Kuzupınarı'nda olduğu gibi burada da kaleye bağlı mevsimlik olarak kullanılan bir yerleşim bulunmaktaydı. Kale ve yakın çevresinde yerleşime dair çeşitli boyutlarda mimari mekânlar tespit edilmiş olsa da bu arkeolojik alanın tarihlenmesine yardımcı olabilecek küçük buluntu tespit edilememiştir (Patac1, 2019b: 146). Her ne kadar bu savunma yapısı ve çevresindeki yapıları tarihlemek için yeterli veriye sahip olmasak da kalede kullanılan inşa yöntemi, bizlere bazı fikirler vererek, bu yapının Demir Çağı içinde kullanılmış olduğunu ifade etmemize yardımcı olmaktadır. Tabi ki bu alanın tarihlenmesi ve işlevi hakkında kesin bir yorum yapabilmek için mutlaka arkeolojik bir kazının yapılması gerekmektedir.

\section{Balçeşme-Kayınlık Kulesi}

Kayınlık kulesi, Göle ilçe sınırlarında bulunan ve Balçeşme köyünün 3.2 km kuzeybatısında yer almaktadır (Harita 1). Arkeolojik alan, kayınlık deresinin yaklaşı $50 \mathrm{~m}$ ve modern karayolunun ise $55 \mathrm{~m}$ kuzeyinde, $2125 \mathrm{~m}$ rakıma sahip kayalık bir tepe üzerinde yer almaktadır (Patacı ve Altun, 2020: 1865).

Kule, doğu-batı yönünde uzanan bir vadinin kuzey kenarında yer alan yükselti üzerinde, kuzeydoğu-güneybatı istikametinde konumlandırılmıştır. Yapının, kuzeyine doğru yükselti artmakta ve kulenin bulunduğu nokta bu yükseltinin daha düşük seviyesindedir. Kulenin güneydoğu ve güneybatısı, Vadinin ise güneyi $5.6 \mathrm{~km}$ boyunca doğu-batı yönünde devam eden ormanlık alandır (Patac1, 2019a: 549). Kule, orta ve büyük boyutlu taşlardan oluşturulmuştur, yapının planı doğu ve batı kenarlarından basık, yarım yuvarlak görünümlü bir forma sahiptir (Resim 7). Kulenin vadiye bakan güney kenarında bir duvar kalıntıs1 bulunmamaktadır. Muhtemelen bu yönde bulunan duvar geçen süre içerisinde çevre şartlarından etkilenerek yıkılmış olmalıdır. Çünkü yapının güney kesiminin, doğal bir kayalıktan oluşan bir uçurum olması bu tahribatın gerçekleşmesini kolaylaştırmıştır olmalıdır (Patacı, 2019a: 549). Balçeşme-Kayınlık Kulesi, planı itibarıyla Bellitepe-Doğu Kulesi ile paralellik göstermektedir ancak Balçeşme Kulesi Bellitepe'dekine oranla çok daha iyi korunmuş bir durumda olduğunu söylenebilir (Patacı, 2019b: 146). Kayınlık kulesi, 18 x 16.5 m'lik bir alanı kaplarken; güney bölümü hariç, yapının biçimine göre batı, kuzey ve doğu yönlerinden saran bir çevre duvarı bulunmaktadır. Çevre duvarı ve ana yapıyı oluşturan mimari yapı aynı işçilikle inşa edilmiştir. Çevre duvarı ile birlikte savunma yapıs1 31 x 26 'm'lik bir alanı kaplamaktadır (Patac1 ve Altun, 2020: 1865). Yapıda korunan duvar yüksekliği, kuzey yönünde 2.22 m'dir. Duvar kalınlıkları yer yer $2.5 \mathrm{~m}$ ve $3.00 \mathrm{~m}$ arasında değişmektedir. Alanda yapılan yüzey incelemeleri sırasında çanak çömlek parçalarının, Demir Çağı ve Ortaçağ’a ait seramikler olduğu gözlemlenmiştir (Resim 8). Mimari açıdan Demir Çağı özelliği gösteren Kayınlık Kulesi'nin ayrıca Ortaçağ'da da kullanım gördüğü düşünülmektedir. Bunun yanında, kulenin teknik açıdan ve konumu açısından benzer özellikler taşıyan, kule yapıları bölgeye yakın olan Erzurum'un Şenkaya ilçesinde yer almaktadır. Akşar ve Çatalkom Gözetleme Kuleleri, Kayınlık kulesi 
gibi bölgeye hâkim bir noktada, yakın çevrelerinde su kaynaklarının olduğu ve orta boyutlu kyklopik taşlardan oluşturulduğu ifade edilirken, araştırmacılar; bölgede tespit edilen seramik buluntularını, Demir Çağı ve Ortaçağ dönemlerine tarihlendirmişlerdir (Ceylan, Bingöl, Ceylan, Özgül, Üngör ve Günaşdı, 2015: 461463). Fakat bu arkeolojik alanlar ile ilgili gerçekleştirilen çalışmalara dair görsel malzemeye yer verilmemesi, bu yapıların incelenmesini olumsuz yönde etkilemektedir. Sonuç olarak Balçeşme-Kayınlık kulesi, mimari özellikleri ve bulunduğu konum itibari ile askerî amaçla inşa edilen, bir savunma ve gözetleme yapısı olarak kullanıldığını düşünmek doğru olacaktır.

\section{Balçeşme-Şipşirik Kulesi}

Kule, 2018 yılı yüzey araştırmaları sırasında tespit edilen arkeolojik alanlar, arasında yer almaktadır. Balçeşme köyünün 1.6 km güneyinde, kuzeygüney yönünde uzana vadinin batı kenarındaki $2220 \mathrm{~m}$ rakımlı bir tepenin zirvesinde bulunmaktadır (Patac1, 2019b: 147; Patac1 ve Altun, 2020: 1866).

Yap1, 9.20 x $7.80 \mathrm{~m}$ boyutlarında büyük ölçüde tahrip olmuş, bir gözetleme kulesi niteliği taşımaktadır. Bu kule, bulunduğu tepeden karayolu ve Şipşirik deresine bakan sarp yamaçta yer almaktadır. Kulenin $123 \mathrm{~m}$ kuzeydoğusunda, kuzey-güney yönünde akan Şipşirik deresi bulunmaktadır. Kule ile Şipşirik deresi arasında, Kayınlık kulesinde olduğu gibi bir modern karayolu yer almaktadır (Patac1, 2019a: 550). Kule, dörtgen planlı olup büyük boyutlu (Kyklopik) bazalt taşlarla kuru duvar tekniğinde inşa edilmiştir (Resim 8). Kuleye giriş, yapının güneybatı köşesinde $90 \mathrm{~cm}$ genişliğinde olan bir açıklık ile sağlanmaktadır. Kapı açıklığının hemen üzerinde, lento işlevinde kullanılan, ancak günümüzde merkezinden iki parçaya ayrılan $2.30 \mathrm{~m}$ uzunluğunda bir blok yer almaktadır. Kulenin en iyi korunan duvar yüksekliği güneybatı köşesinde, maksimum 2.60 m'dir (Resim 9). Bu yöndeki duvar kalıntısı dışında yapıya ait olan diğer duvar kalıntıları, arazi seviyesinde korunmuştur. Temel seviyesinde korunan kalıntılar arasında, kulenin $2.30 \mathrm{~m}$ güney kesiminde tespit edilen ve bir çevre duvarı olduğu düşünülen 5. $20 \mathrm{~m}$ uzunluğunda bir duvar kalıntısı yer almaktadır. Güney yönde olduğu gibi dörtgen yapının kuzey kesiminde de birkaç sıra taş bloktan oluşan bir duvar kalıntısı bulunmaktadır (Patac1, 2019b: 147).

Arkeolojik alanda, tek mimari buluntu gözetleme kulesi ile sınırlı değildir. Kulenin batısında ve güneyindeki arazi üzerinde, kullanım amaçları hakkında yorum yapılamayacak kadar kötü korunmuş temel seviyesinde mimari kalıntılar tespit edilmiştir (Patacı ve Altun, 2020: 1866). Ayrıca kulenin $60 \mathrm{~m}$ güneyinde bir yapı kalıntısı daha alanın doğu sınırında yer almaktadır (Patacı, 2019a:551). Bu kalıntıya ait moloz yığınları, yapının bulunduğu noktada 28 × 8 m'lik bir alanı kaplamaktadır. Mimari kalıntının, batı kenarında yer yer arazi seviyesinde korunmuş in situ duvar kalıntıları, $14.45 \mathrm{~m}$ uzunluğunda kuzey-güney yönünde bulunmaktadır (Resim 10). Aynı yapının hemen doğusunda sarp kayalık yamacın sınırında dörtgen planlı, arazi seviyesinde belli belirsiz temel duvarlarına sahip bazı yapılar tespit edilmiş ancak arazideki yoğun bitki örtüsü nedeniyle verimli incelemeler yapılamamıştır (Patacı ve Altun, 2020: 1866). Arkeolojik alan sınırları 
içerisinde yapılan yüzey incelemeleri sonunda, Ortaçağ seramiği ve birkaç adet Demir Çağı'na tarihlendirilebilecek seramik parçaları tespit edilmiştir (Resim 11). Az sayıdaki seramik buluntusu, arkeolojik alanın tarihi hakkında bir fikir oluşturmak için yetersizdir fakat kulenin duvar örgüsü, Ardahan'da ve Göle ilçesinde (Kayınlık Kulesi vb.) bilinen ve askeri amaçlı kullanılan savunma yapılarının özellikleri ile benzerlik göstermektedir. Bu benzerlikler, genellikle yapılarda kullanılan büyük boyutlu taşlar ve bu taşların duvarlardaki az işçilikli örgü yöntemine dayandırılmaktadır. Kuru duvar tekniğinde ve kyklopik yapı taşlarıyla oluşturulan bu kalıntıların Erken Demir Çağı yapıları ile paralellik taşıması (Smith ve Kafadarian, 1996: 24-24) tarihlendirilebilmeleri için önemli bir etmendir. Her ne kadar bu yapıları tarihlemede genellikle göreceli tarihleme yöntemi kullanılsa da bu tip yapılar için net bir tarih belirlemek, arkeolojik kazılarla mümkün olmaktadır (Patacı, 2019a: 551).

\section{Balçeşme-Tekmezar Kulesi ve Yerleşimi}

Tekmezar Kulesi ve yerleşimi adı altında ele alınan arkeolojik alan, Balçeşme köyünün sınırlarında, köy merkezinin $700 \mathrm{~m}$ kadar doğusunda bulunmaktadır (Patacı, 2019b: 148). 2018 yılı yüzey araştırmaları sırasında tespit edilen kule ve yerleşim yeri, bu dönemde bulunan arkeolojik alanlar arasında yer almaktadır (Pataci ve Altun, 2020: 1866).

Arkeolojik alan, adından da anlaşılacağı üzere, bir gözetleme kulesi ve araziye yayılmış olan yerleşim yapılarından oluşmaktadır (Resim 12). Bu yapı merkezi, Kura Nehri'ne bağlı Tekmezar Deresi'nin bulunduğu vadinin güney kenarında, aynı derenin yaklaşık $55 \mathrm{~m}$ kadar güneyinde kayalık bir tepe üzerinde yer almaktadır. Bu alandaki kalıntılar, vadi ile Kars'a doğru uzanan karayolu arasındaki düzlükte, $2180 \mathrm{~m}$ rakımlı tepe üzerinde, kabaca 100 x 50 m'lik bir arazi üzerinde bulunmaktadır (Patacı, 2019a: 552). Kulenin güneyi, doğusu ve batısındaki arazi üzerinde eski bir yerleşime dair kare ve dikdörtgen planlı yapılardan oluşan, bir kalıntı topluluğu gözlemlenmiştir. Bu kalıntı kümesi, yaklaşık olarak 15 veya 20 adet mekândan oluşmaktadır. Gözetleme kulesi, kayalık bir zemin üzerinde inşa edilmiş ve yerleşim kalıntılarının doğu yarısında ve yerleşim yerine göre birkaç metre daha yüksekte bulunmaktadır. Kulenin, vadiye dönük kısmında Kayınlık Kulesi'nde olduğu gibi bir duvar kalıntısı tespit edilememiştir.

Yapının doğu, batı ve kuzey yönlerinde yer alan duvarları arazi seviyesinde korunmuştur (Patac1, 2019a: 552). Kulenin planı, korunan duvar kalıntılarından anlaşıldığ1 üzere dörtgen planlıdır (Resim 13). Gözetleme kulesinin duvar kalıntılarından alınan ölçüler ile batı duvarı maksimum $11 \mathrm{~m}$; doğu duvarı $6.80 \mathrm{~m}$; güney duvarı ise $10.24 \mathrm{~m}$ uzunluğa sahiptir. Korunan duvar yüksekliği güney duvarında $1.60 \mathrm{~m}$, bu alanda kullanılan taş blokların boyutları ise $1.50 \mathrm{~m}$ ile $1.00 \mathrm{~m}$ arasında değişmektedir. Yapının duvar kalınlıkları ise $1.90 \mathrm{~m}$ ve 2.00 arasındadır (Patac1 ve Altun, 2020: 1866). Kulenin, giriş bölümü ise incelemeler sırasında tespit edilememiş ancak bu yapının, kuzey ve batı yönlerinde yüksek kayalık alanların olması, bu alana girişin güney veya doğu yönünde olduğunu bizlere 
düşündürmektedir (Patacı, 2019b: 148). Kulenin batı kenarında yer alan mekânlar, kuleden batıya doğru yaklaşık 70 m'lik bir alanı kaplamaktadır.

Kule çevresinde gözlemlenen seramik buluntularının büyük çoğunluğu Ortaçağ özelliği taşırken, birkaç adet Demir Çağı seramiği de tespit edilmiştir. Her ne kadar arkeolojik alanda seramik adına yoğunluk Ortaçağ Dönemi üzerinde yoğunlaşsa da eldeki diğer veriler, bu arkeolojik alandaki gözetleme kulesinin Demir Çağında inşa edildiği ve Ortaçağda da kullanılmaya devam edildiğini göstermektedir (Patac1, 2019a: 552-553). Kulenin, Demir Çağı'na tarihlendirilmesini, kolaylaştıracak veri ve bilgiler; Ardahan'da bulunan ve bu yapıyla mimari açıdan benzeşen diğer askeri yapılar, İlin merkez ilçesindeki Ölçek, Kocaköy ve Hasköy Demir çağ 1 kulelerinin teknik ve mimari özellikleri göz önüne alınarak gerçekleştirilebilir (Patacı-Laflı, 2019d: 263-264; Patacı-Laflı, 2017: 115126).

\section{Sonuc}

Göle İlçesi'nde 1995-1997 ve 2016-2018 yıllarında gerçekleştirilen yüzey araştırmaları ile bölgenin, daha iyi anlaşılabilmesi adına önemli veriler elde edilmiştir. Konumu itibari ile Göle; Kuzeydoğu Anadolu bölgesinin en yüksek yerleşim alanlarının başında gelmektedir. Bölge, kuzeyden yani Kafkaslar üzerinden gelen Sibirya soğuk hava dalgasının etkisi altında kalarak, yıl boyu soğuk bir ortama sahip olduğu gözlemlenmektedir. Sert karasal iklim tipi ve yüksek yağış miktarı, bölgede; gür sarıçam ormanları, Supalpin-alpin ve çayır step bitkilerinin yetişmesine olanak sunmuştur. Diğer yandan bölge yağışlar ile sulak bir arazi haline gelirken bol miktarda biriken su, ilçedeki önemli çay ve derelerin beslenmesini de sağlamıştır. Biriken bu su kaynakları; Kayınlık, Türkmen ve Kür Çaylarının yağışların desteği ile Kuzeydoğu Anadolu ve Transkafkasya bölgelerinin en önemli su kaynağı olan Kura Nehri'nin meydana gelmesini sağlamışlardır. Ancak Göle, zengin su kaynağına ve bitki çeşitliliğine sahip olsa da bu unsurlar, bölgede yaşayan halkın geçimlerini sağlayacakları tarımsal faaliyetlerin önüne geçtiği de anlaşılmaktadır. $\mathrm{Bu}$ nedenle de bölgede çok az miktarda tarım ürünü yetişirken, bölge halkı ihtiyaçlarını karşılamak için ve arazi koşullarının da uygun olmasından dolayı kendilerini, geçmişten gelen bir gelenek ile yaylacılık ve büyükbaş hayvancılık alanında geliştirdikleri anlaşılmaktadır.

Göle'nin, çoğunlukla Kuzeydoğu Anadolu bölgesindeki İlleri kapsayan ve genel araştırma projeleri içerisinde göz ucu ile incelenen bir bölge durumunda kaldığı gözlemlenmiştir. Fakat bu durum, 1995-1997 ve 2016-2018 y1llarında İl bazında gerçekleştirilen yüzey araştırmaları ile kısmen de olsa ile aşılmıştır.

Genel olarak bölge adına gerçekleştirilen ilk araştırmalar, yer aldığı coğrafyanın da etkisi ile Ortaçağ'a ait olan kültürel kalıntılar üzerine odaklanıldığını, net bir şekilde ortaya koymuştur. Ancak bu süreçte Kalkolitik, Tunç ve Demir Çağları yeterince irdelenmemiştir. Yapılan yakın dönem araştırmalarıyla, coğrafyanın Demir Çağı vaziyeti, kültürü ve savunma mimarisi üzerine en azından kayda değer bazı verilere ulaşıldığı anlaşılmaktadır. Diğer yandan bölgede gerçekleştirilen çalışmalar neticesinde Göle'nin adının kökeni hakkında bazı görüşlerin ileri sürülmesi de imkan bulmuştur. Buna göre, Ortaçağ 
(Gürcüce: Kola, Ermenice: Kol) ve sonraki dönemlerde (Osmanlı Döneminde: Merdinik ve Ardahanı-Küçük) farklı isimler ile bölgeden bahsedilmiştir. Ne var ki, bölgenin Demir Çağı'ndaki ismi hakkında net bir bilgi yoktur. Konu hakkında bölgede araştırmalar gerçekleştirilen Edwards (1988) ve Köroğlu (2001) Göle kelimesini, MÖ I. binyılda Van Gölü Havzasında yer alan Urartu krallarından II. Sarduri'nin kuzey seferlerini anlattı̆̆ 'Analıkız' stelinde geçen 'Qulha' kelimesi ile bağdaştırılabileceğini ileri sürmektedir. Tabi ki bu bağlantının daha anlaşılabilir olması için ileriki yıllarda bölgede gerçekleştirilecek detaylı çalışmalar ile bu konudaki eksikliğin giderileceği umulmaktadır. Kanaatimizce, Urartu krallığı yazıtlarında geçen bölge adının, Köroğlu (2001) tarafından öne sürülen mantıklı ve tutarlı gerekçeler ile daha kabul edilebilir olduğunu da vurgulamak gerekmektedir. Esasında adı geçen yazıtta belirtilen bölge adı, araştırmacılarca Doğu Karadeniz kıyısında kurulan Kolkhis (MÖ IX-VIII) ile daha çok ilişkilendirilmektedir.

Göle'nin Eskiçağ’ 1 adına tespit edilen arkeolojik alanlar, tarafımızca belirli yapısal özellikler göz önüne alınmak şartı ile savunma mimarisi içinde sıkça kullanılan, Kale ve Kule yapıları olarak değerlendirilmiştir. Bu nedenle, 2016-2018 yılları arasında tespit edilen savunma yapıları olan kale ve kuleler, genel olarak yüksek tepelik alanların kayalık bölümlerinde, çoğu zaman su kaynaklarına yakın alanlarda ve araziden sağlanan inşa malzemeleri ile bulundukları arazinin topografik yapısına uygun şekillerde kurulmuşlardır. Bölgede kuru duvar tekniğinde inşa edilen, toplamda beş kale ve beş kule savunma yapısı yer almaktadır. Bu arkeolojik alanlardan elde edilen veriler yani mimari ve çanakçömlek buluntularının bir kısmı, Demir Çağı kültürü ile paralellik göstermektedir. Diğer yandan incelediğimiz mimari yapılar, yapım tekniği açısından birbirleri arasında tutarlı bir benzerlik gösterirken, bazı yerleşimler ise örneğin; Kayaaltı (Omega) Kalesi, Kuzupınarı Kalesi ve Yerleşimi ve Bellitepe-Batı Kulesi gibi savunma yapıları, Kuzeydoğu Anadolu bölgesinde mimari açıdan ender görülen, farklı planlara sahiptirler. Bu durumun yanı sıra, Kuzupınarı arkeolojik alanı savunma mimarisi yanında daha küçük yerleşim mekânlarına sahip olması açısından Çobanköy Kalesi ve Yerleşimi ile de benzerdir. Bu alanlarda yer alan küçük boyutlu mimari yapıların işlevleri konusunda detaylı araştırma ve kazı çalışmaları yapılmadan net bir yorum yapabilmek mümkün gözükmemektedir; ancak özellikle Çobanköy'ün işlevi hususunda yapılacak en genel yorum, daha çok sivil yaşama yönelik ve hayvancılık faaliyetleri doğrultusunda kurulmuş bir alan olması gerektiği yönündedir. Bellitepe ve Durucasu savunma yapıları diğer kale yapılarından daha az korunmuş durumdadır. Fakat bu yapıların mimari özellikleri ve küçük arkeolojik buluntuları üzerinden yapılan değerlendirmeler ile bu alanların da Demir Çağı mimarisini yansıtan özellikler taşıdıkları anlaşılmaktadır. Göle'deki Kule yapıları ise, özellikle Ardahan sınırları içinde yoğun olarak rastlanılan savunma yapılarıdır. Kuleler, çoğunlukla bir kayalık alan üzerinde yer alırken bu alanın uçuruma en yakın noktasında oluşturulmuşlardır. Genellikle yakın çevrelerinde tatlı su kaynakları bulunurken, bu yapıların daha büyük boyutlu kaleler ve diğer kule yapıları ile yakın mesafede yer aldıkları gözlemlenmiştir (Harita 1). Bellitepe-Batı ve Doğu kulesi, Balçeşme-Kayınlık, Şipşirik ve 
Tekmezar kuleleri bu durumu en iyi yansıtan savunma yapılarıdır. Bu arkeolojik alanların Ardahan dışındaki yakın coğrafyada tespit edilmiş benzer özelliklere sahip örneklerinin sayıca az olması, bu yapıların anlaşılmasını zorlaştırmaktadır. Göle'deki Demir Çağı savunma yapılarının mimarisini ve işlevlerini daha iyi anlayabilmek için bölgede mutlaka arkeolojik kazıların gerçekleştirilmesi gerekmektedir.

\section{KAYNAKÇA}

Atalay, İ., Tetik, M. ve Yılmaz, Ö. (1985). Kuzeydoğu Anadolu'nun Ekosistemleri. Ormancılık Araştırma Enstitüsü Yayınları Teknik Bülten Serisi No:141, Ankara.

Arslan, M. (2000). Kolkhis Bölgesi'nin Tarihi Coğrafyasına İlişkin Bazı Notlar, Arkeoloji ve Sanat, 97, 26-40.

Bayram, F. ve Yazar, T. (2010). "Artvin, Erzurum, Ardahan İli ve İlçelerinde Ortaçağ Gürcü Mimarisi Yüzey Araştırmas1-2009”, 28. Araştırma Sonuçları Toplantısı 1.Cilt, İstanbul, 1-18.

Ceylan, A., Bingöl, A., Ceylan, N., Özgül, O., Üngör, İ. ve Günaşdı, Y. (2015). "2014 Y1lı Erzincan-Erzurum İlleri Yüzey Araştırmaları", 33. Araştırma Sonuçları Toplantısı 1. Cilt, Erzurum, 447-472.

Çiloğlu, F. (1993). Dilden Dine, Edebiyattan Sanata Gürcülerin Tarihi. Anıt Yayınları, İstanbul.

Çilingiroğlu, A. (1997). Urartu Krallı̆ğ, Tarihi ve Sanatı, Yaşar Eğitim ve Kültür Vakfi, İzmir.

Edwards, W.R. (1986). "The Fortifications Of Artvin: A Second Preliminary Report On The Marchlands Of Northeast Turkey", Dumbarton Oaks Papers 40, 165-182. Erişim adresi: http://www.jstor.org/stable/1291536

Edwards, W.R. (1988). "The Vale of Kola: A Final Preliminary Report on the Marchlands of Northeast Turkey", Dumbarton Oaks Papers 42, 119141. Erişim adresi: http://www.jstor.org/stable/1291592

Erginal, E.A. (2016). “Ardahan İlinin Coğrafik Özellikleri”. Sami Patacı (Ed.), Ardahan Kale ve Kuleleri (s. 10-12) içinde, Kars, Serhat Kalkınma Ajansı (SERKA) Yayınları.

Honigman, E. (1970). Bizans Devletinin Doğu Sınırı, (Fikret Iş1ltan, Çev.), İstanbul Üniversitesi Edebiyat Fakültesi Yayınları NO: 1528, İstanbul.

Patac1, S. (2015). Transkafkasya Arkeolojisi Kapsamında Ardahan, Yeni Türkiye Kafkaslar Özel Saylst-II 72, 52-86.

Patac1, S. ve Lafl1, E. (2016). Field Surveys in Ardahan in 2015, Anatolia Antiqua 33, 281-297.

Patac1, S. ve Laflı, E. (2017). Field Surveys in Ardahan in 2016. Anatolia Antiqua 25, 115-126.

Patacı, S. (2019a). Göle'deki Balçeşme Arkeolojik Buluntuları/Archaeological Finds of Balçeşme in Göle, Uluslararası Sosyal Araştırmalar Dergisi 12, (66), 547-556. 
Patacı, S. (2019b). Yeni Araştırmaların Sonuçlarına Göre Ardahan'ın Arkeolojik Buluntulart. İhsan Kurtbaş (Ed.), Ardahan Değerlemeleri -I- Sosyo-

Politik. Kültürel ve İktisadi Bağlamda Değerler, Potansiyeller ve Yaklaşımlar (s.119-163), içinde, Ankara, Nobel Bilimsel Eserler.

Patacı, S. (2019c). Ardahan'daki Gölgeli ve Çobanköy Demir Çağı Alanları,

Karadeniz Uluslararası Bilimsel Dergi 41, 106-119.

Patacı, S. ve Lafl1, E. (2019). Ardahan'da Arkeolojik Araştırmalar: 2015 Yılı

Yüzey Araştırması, Timur Demir, Makbule Ekici, Münteha Şahan

Dinç, Çağrı Murat Tarhan (Ed.), Rıfat Ergeç'e Armağan (s.261-

276) içinde, Gaziantep, Bilgin Kültür Sanat Yayınları.

Patac1, S. ve Oral-Patac1, Ö. (2020). Ardahan İli 2017 Y1lı Arkeolojik Yüzey

Araştırması, Karadeniz Uluslararası Bilimsel Dergi 47, 223-255.

Patac1, S. ve Altun, S. (2020). Ardahan İli 2018 Y1lı Arkeolojik Yüzey Araştırması: Genel Değerlendirme, Anemon Muş Alparslan

Üniversitesi Sosyal Bilimler Dergisi 8, (6), 1863-1872.

Koçman, A. (1990). Kura Nehri Yukarı Havzasında Doğal Bitki Toplulukları ve Yetişme Ortamı Özellikleri (NE Anadolu), Ege Coğrafya Dergisi 11, (5), 44-52.

Köroğlu, K. (1996). "1995 Yılı Artvin-Ardahan İlleri Yüzey Araştırması”, XIV. Araştırma Sonuçları Toplantısı I. Ankara, 369-395.

Kadirlioğlu-Leube, M., Yazar, T. ve Karaca, Z. (1996). "1995 Yılı Tao-Klardjetie Yüzey Araştırması”. XIV. Araştırma Sonuçları Toplantısı I. Ankara, 397-421.

Köroğlu, K. (1998). "1996 Yılı Artvin-Ardahan İlleri Yüzey Araştırması”, XV. Araştırma Sonuçları Toplantısı I. Cilt, Ankara, 127-156.

Köroğlu, K. (1999). "1997 Yılı Artvin-Ardahan İlleri Yüzey Araştırması”, XVI. Araştırma sonuçları Toplantısı I. Cilt”, (25-29 Mayıs 1998 Tarsus) Tarsus, 143-160.

Konukçu, E. (1999). Ardahan Tarihi, Ajans-Türk Basın Basım A.Ş., Ankara.

Kadiroğlu-Leube, M., Yazar, T. ve Karaca, Z. (2001). "Ortaçağ Gürcü Mimarisi 2000 Yılı Yüzey Araştırması”, 19. Araştırma Sonuçları Toplantısı 1. Cilt, Ankara, 93-100.

Köroğlu, K. (2001). Urartu Krallı̆̆ı'nın Kuzey Yayılımı ve Qulha Ülkesinin Tarihi Coğrafyas1, Belleten LXIV-241, 717-741.

Kızgut, R. (2016). Eskiçağ Tarihinde Kolkhis Bölgesi (Yayımlanmamış Doktora Tezi). Selçuk Üniversitesi, Sosyal Bilimler Enstitüsü, Konya.

Smith, T.A. ve Kafadarian, K. (1996). New Plans of Early Iron Age And Urartian Fortresses in Armania: A Preliminary Report on the Ancient Landscapes Project, Iran 34, (1), s. 23-37. doi: $10.2307 / 4299942$

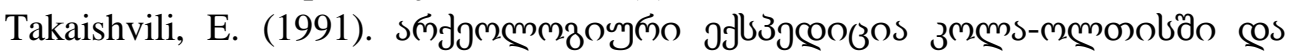

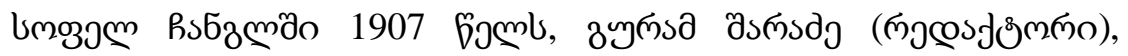

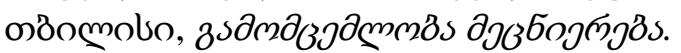

Erişim adresi: http://saunje.ge/index.php?id=1521\&lang=ru 


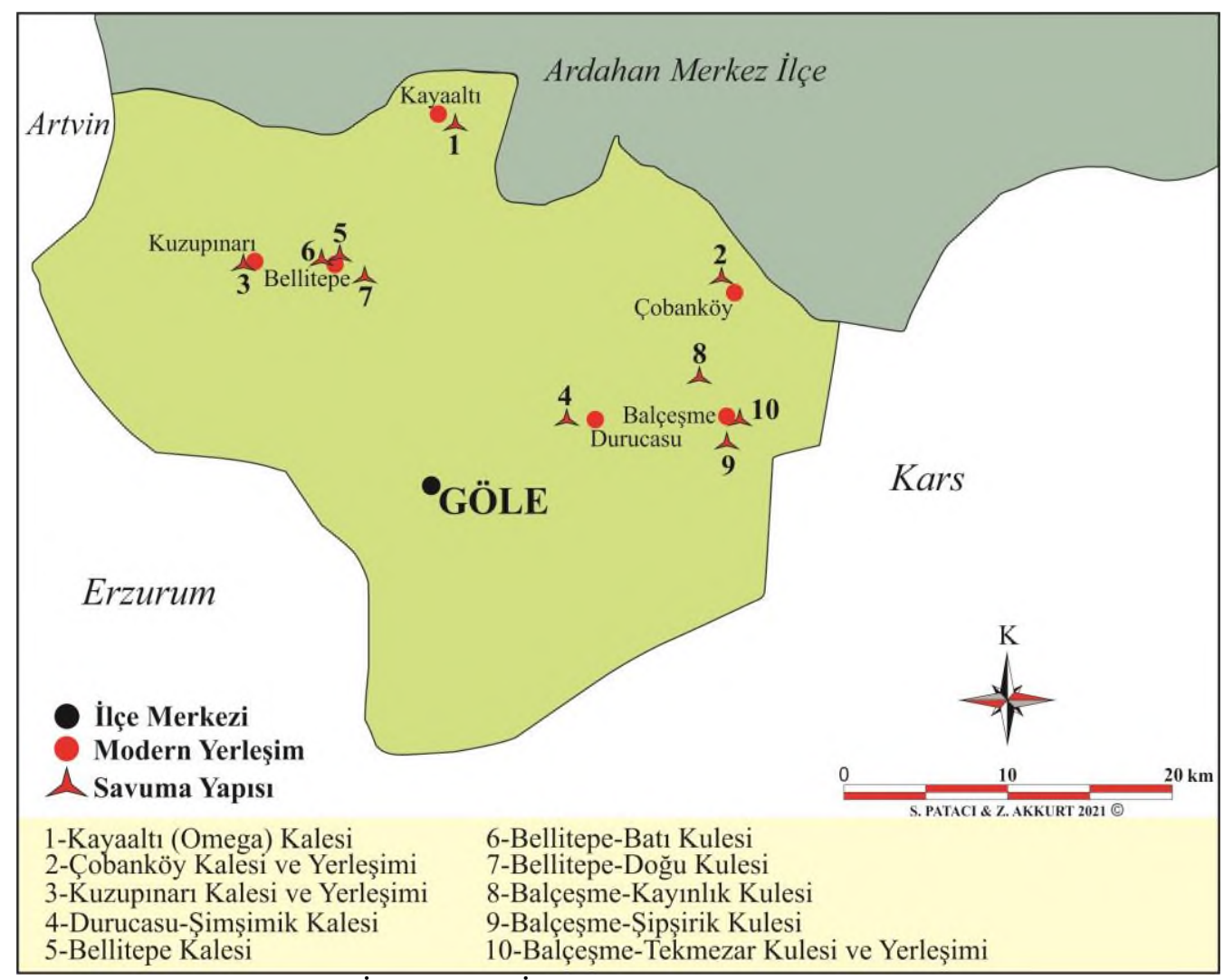

Harita 1. Ardahan İlinin Göle İlçesindeki Demir Çağı savunma yapıları 
Zekeriye AKKURT - Sami PATACI

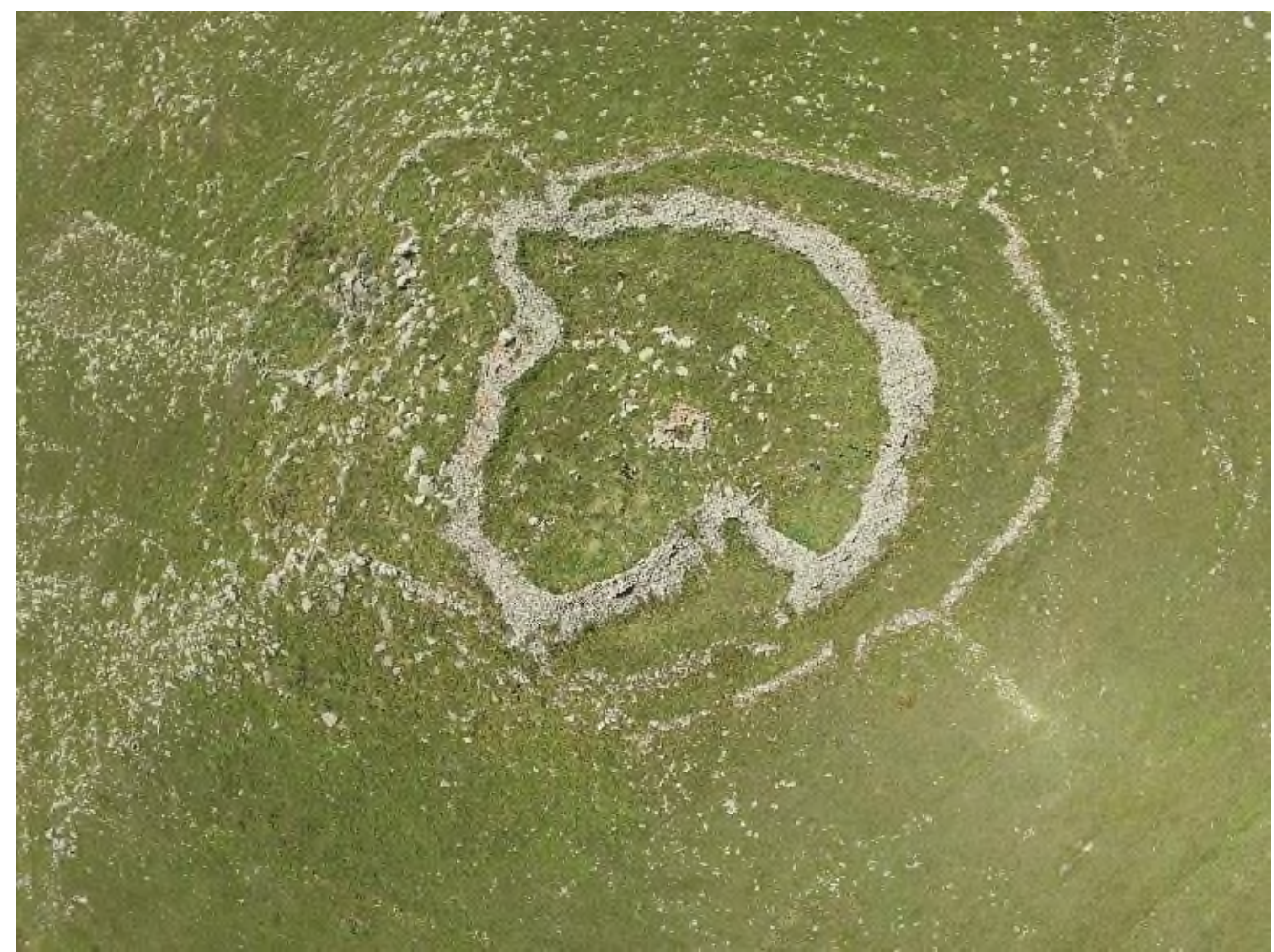

Resim 1. Kayaaltı (Omega) Kalesi hava fotoğrafi. 


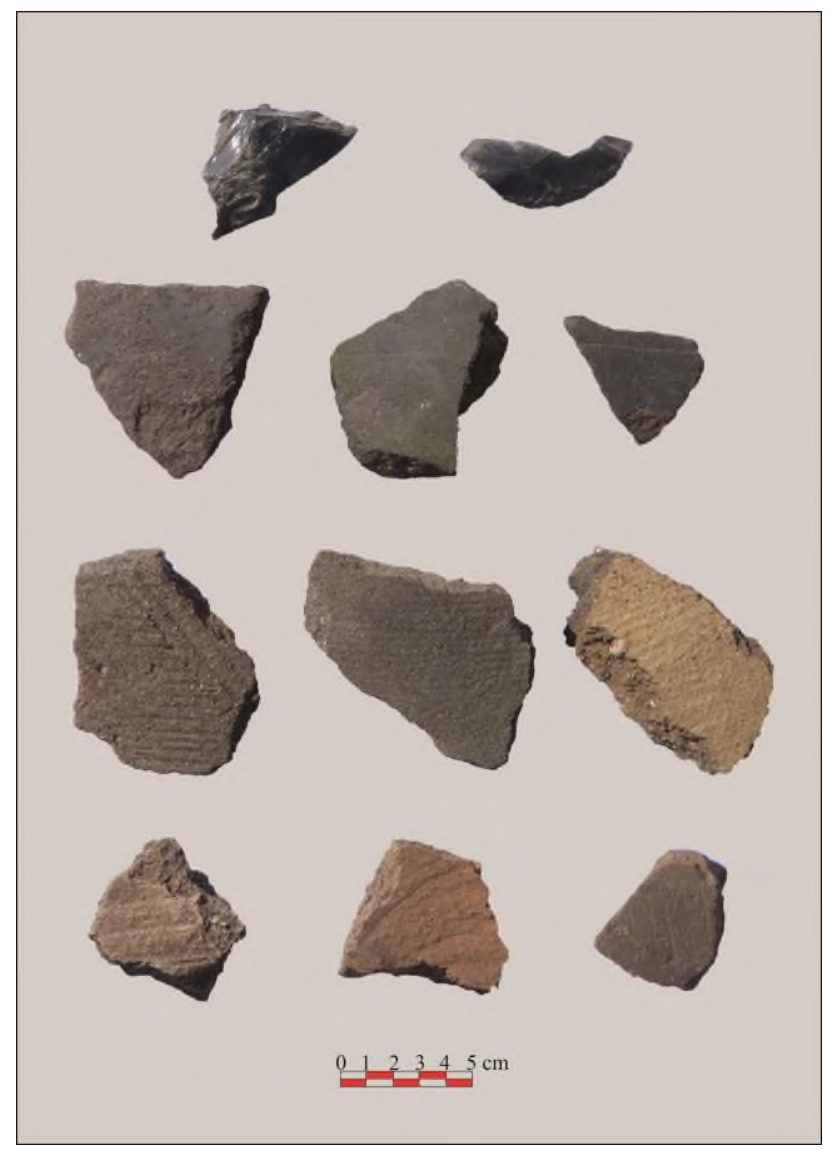

Resim 2. Kayaaltı (Omega) Kalesi küçük arkeolojik buluntuları. 


\section{Zekeriye AKKURT - Sami PATACI}

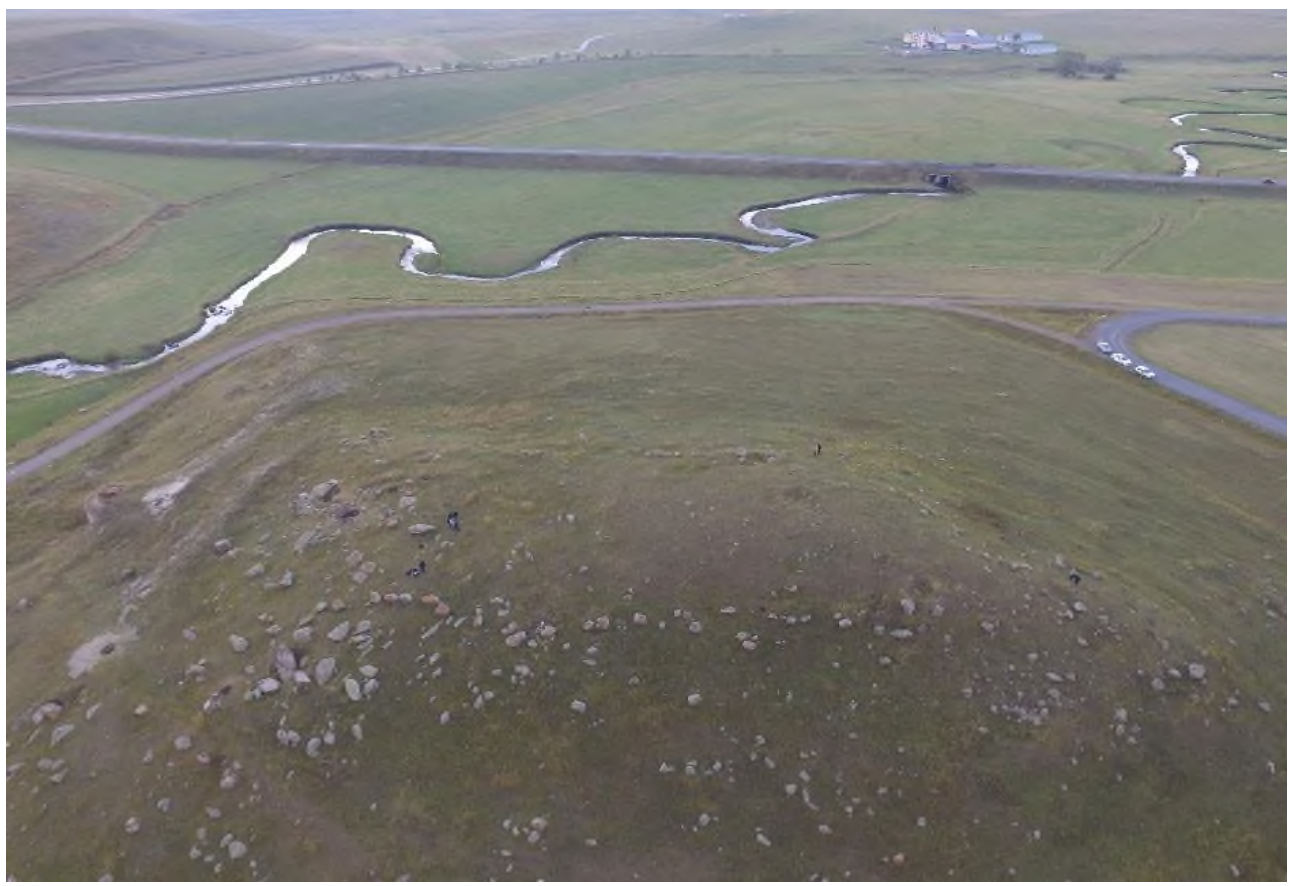

Resim 3. Durucasu-Şimşimik Kalesi hava fotoğrafi

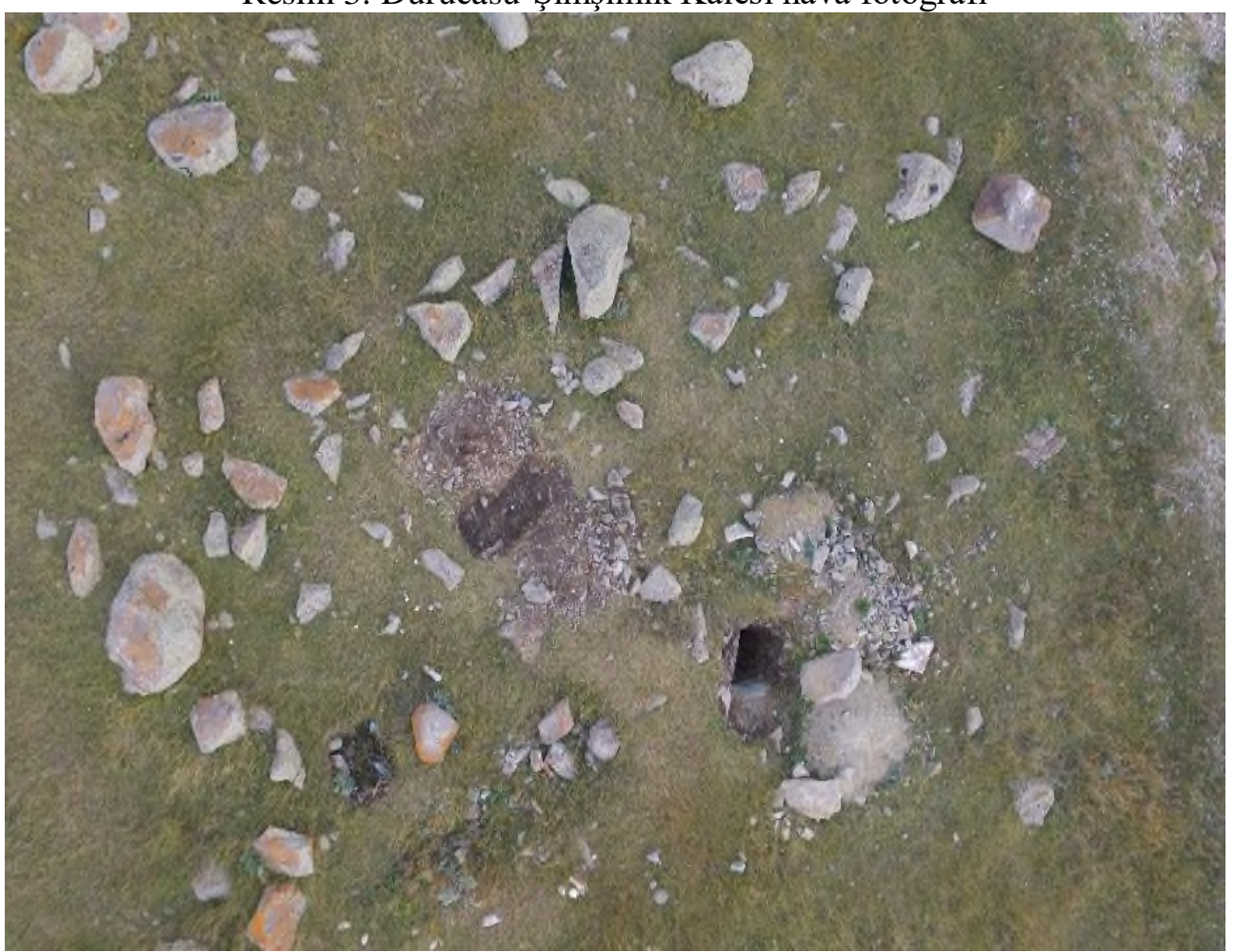


Resim 4. Durucasu-Şimşimik Kalesi kaçak kazı çukurları.

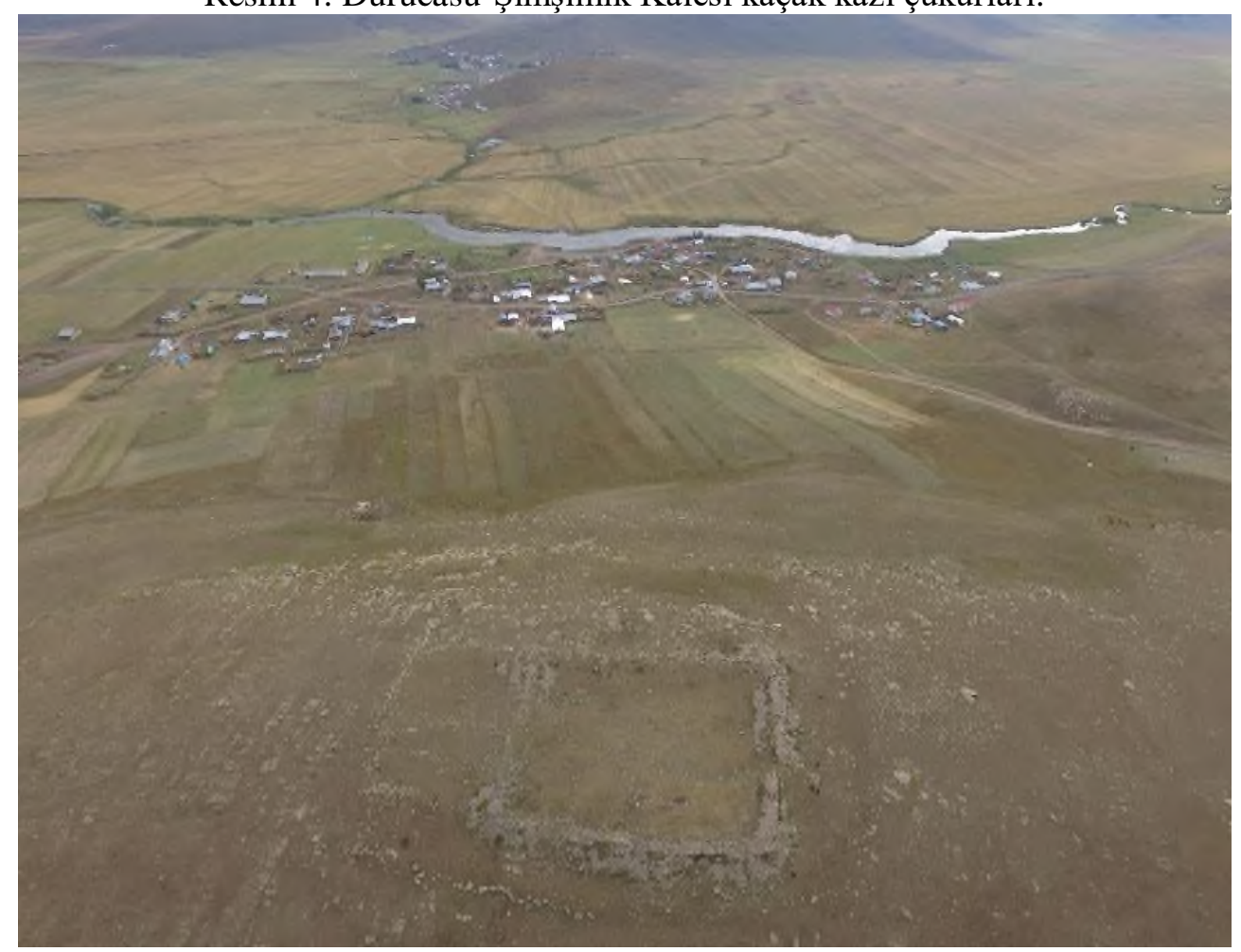

Resim 5. Bellitepe Kalesi hava fotoğrafi. 
Zekeriye AKKURT - Sami PATACI

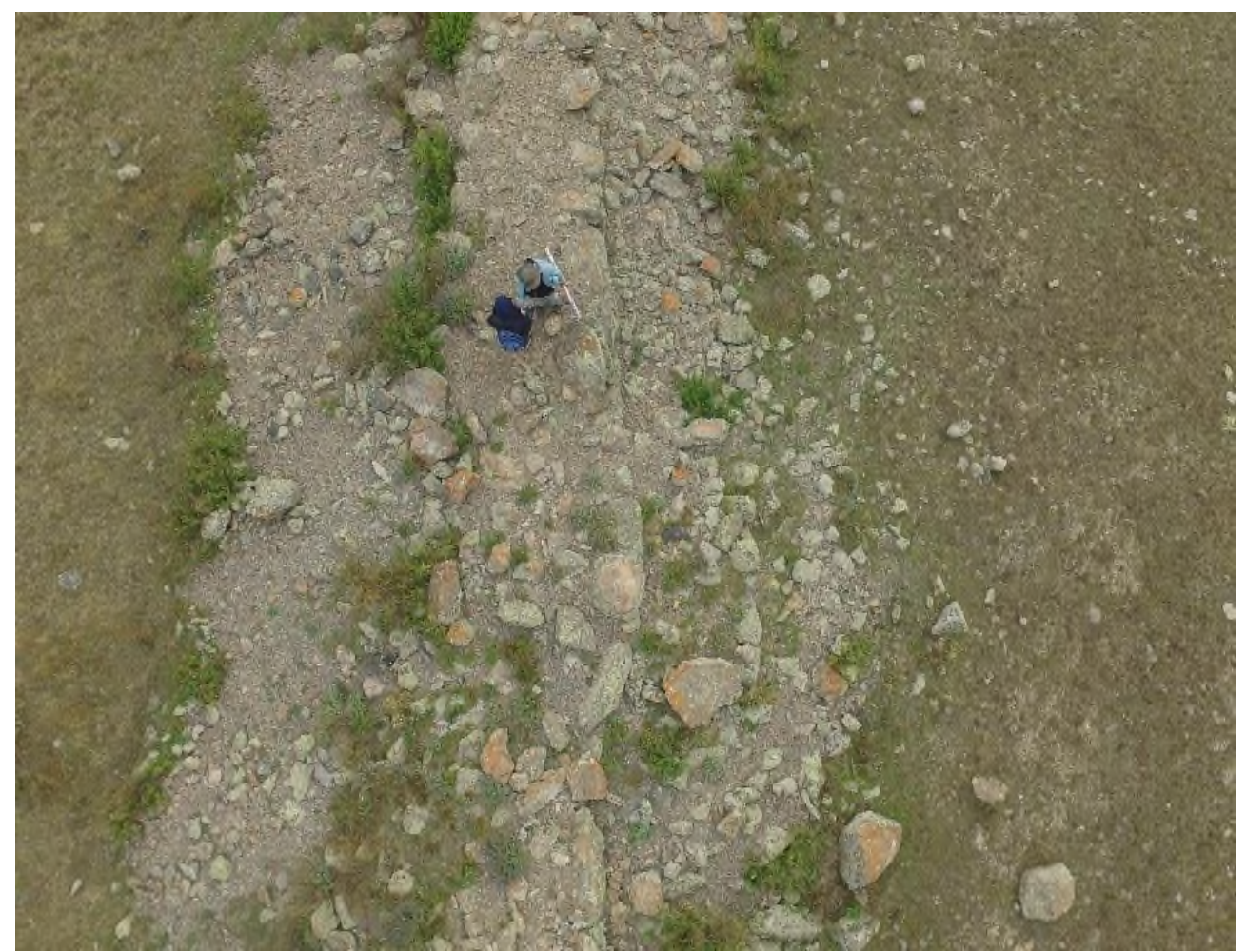

Resim 6. Bellitepe Kalesi duvar yapısı. 
Ardahan'ın Göle İlçesindeki Demir Çağı Savunma Yapıları

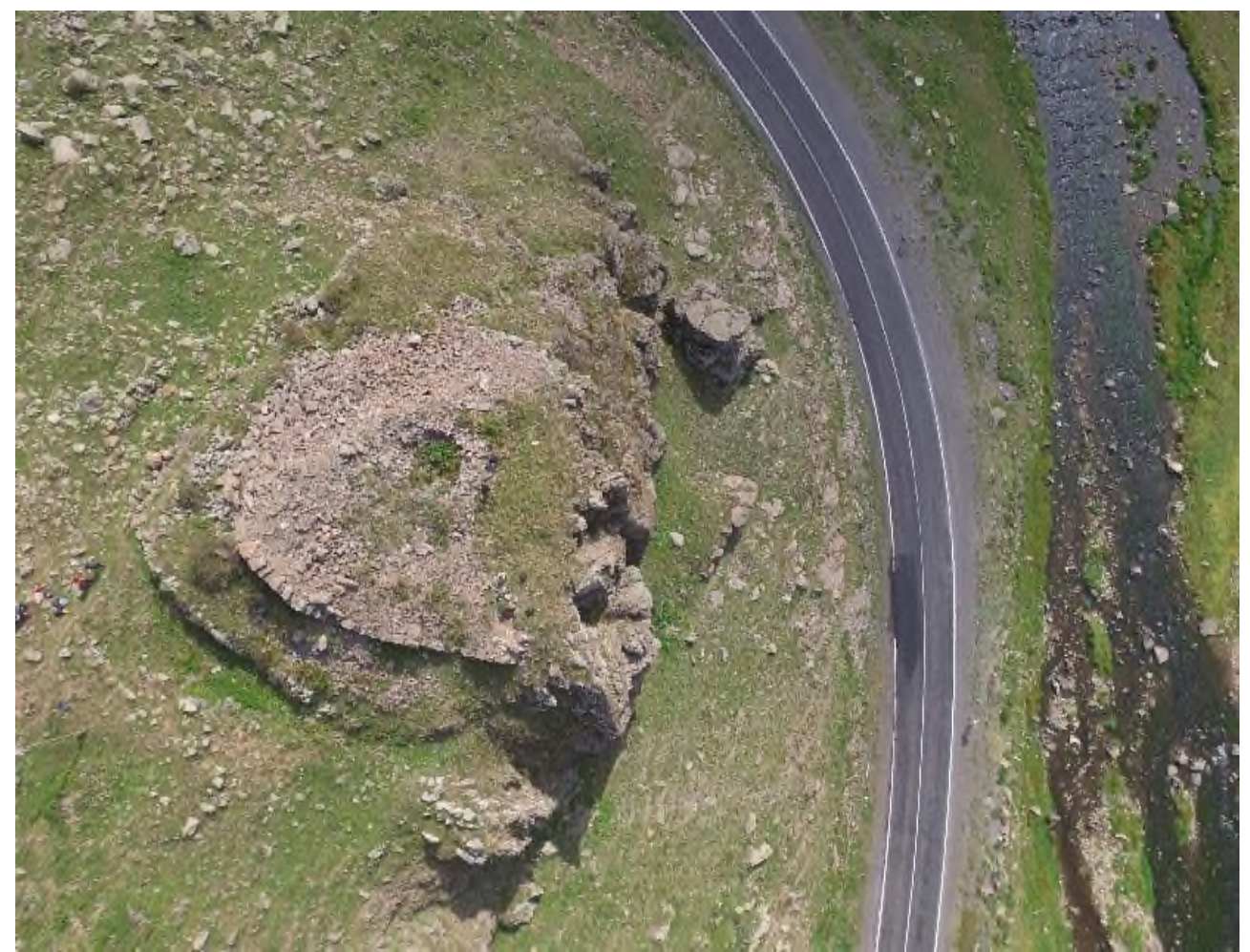

Resim 7. Balçeşme-Kayınlık Kulesi hava fotoğrafi. 
Zekeriye AKKURT - Sami PATACI

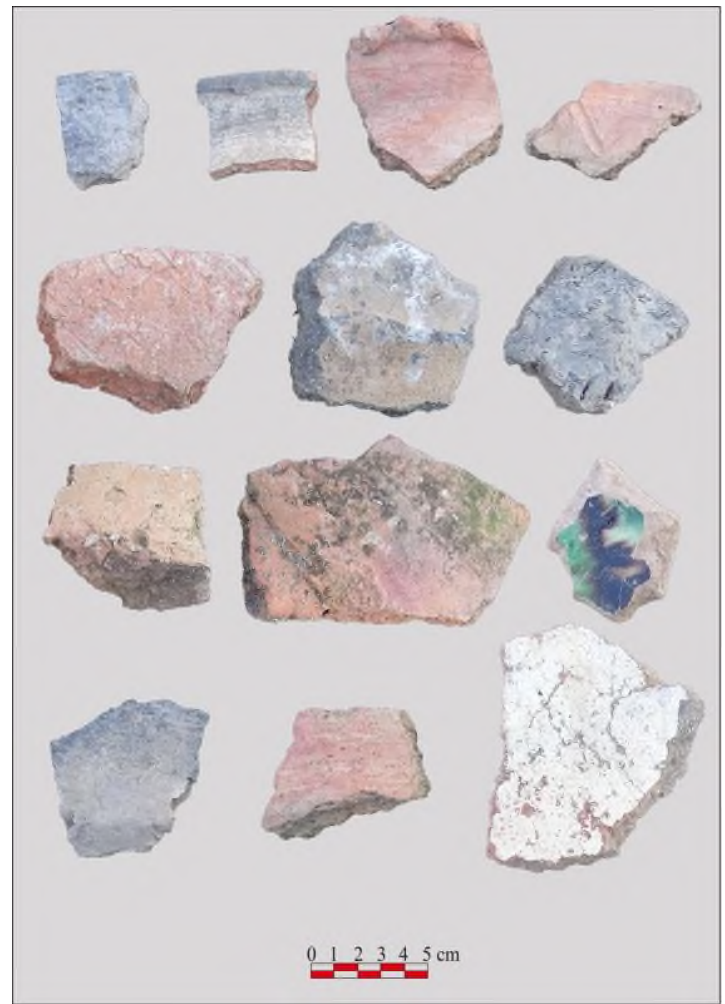

Resim 8. Balçeşme-Kayınlık Kulesi çanak-çömlek buluntuları. 


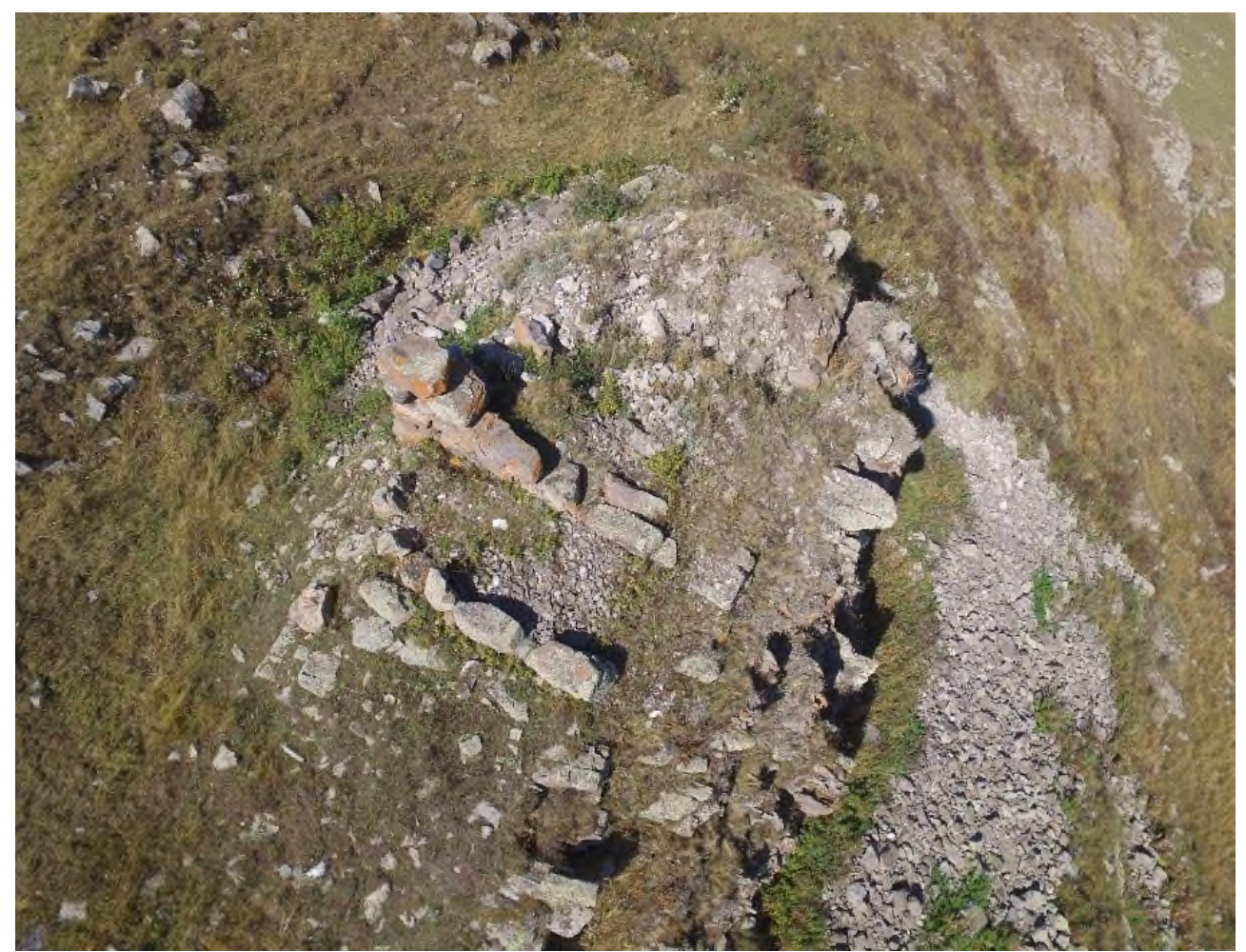

Resim 9. Balçeşme-Şipşirik Kulesi hava fotoğrafi. 


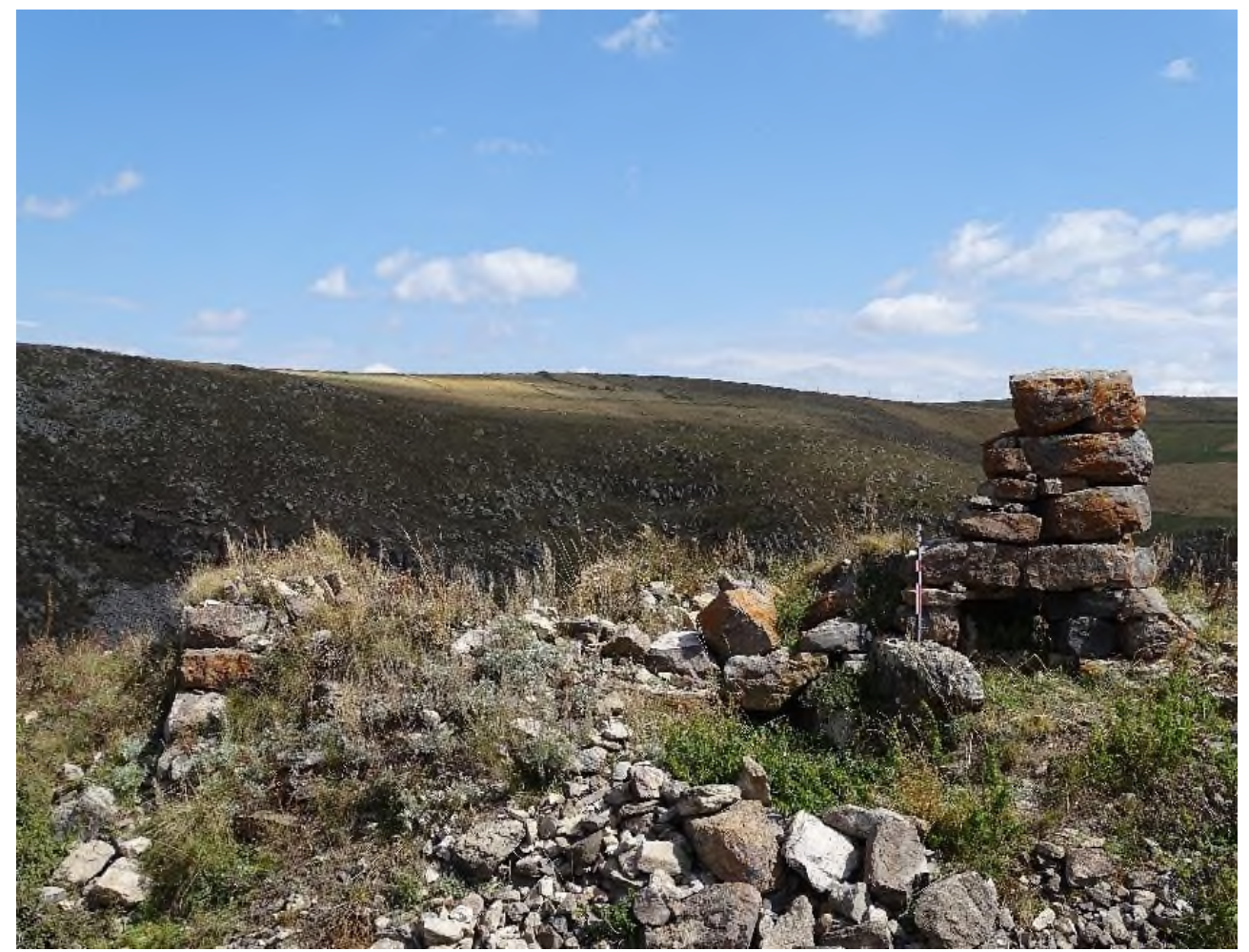

Resim 10. Balçeşme-Şipşirik Kulesi kapı girişi ve duvar kalıntısı.

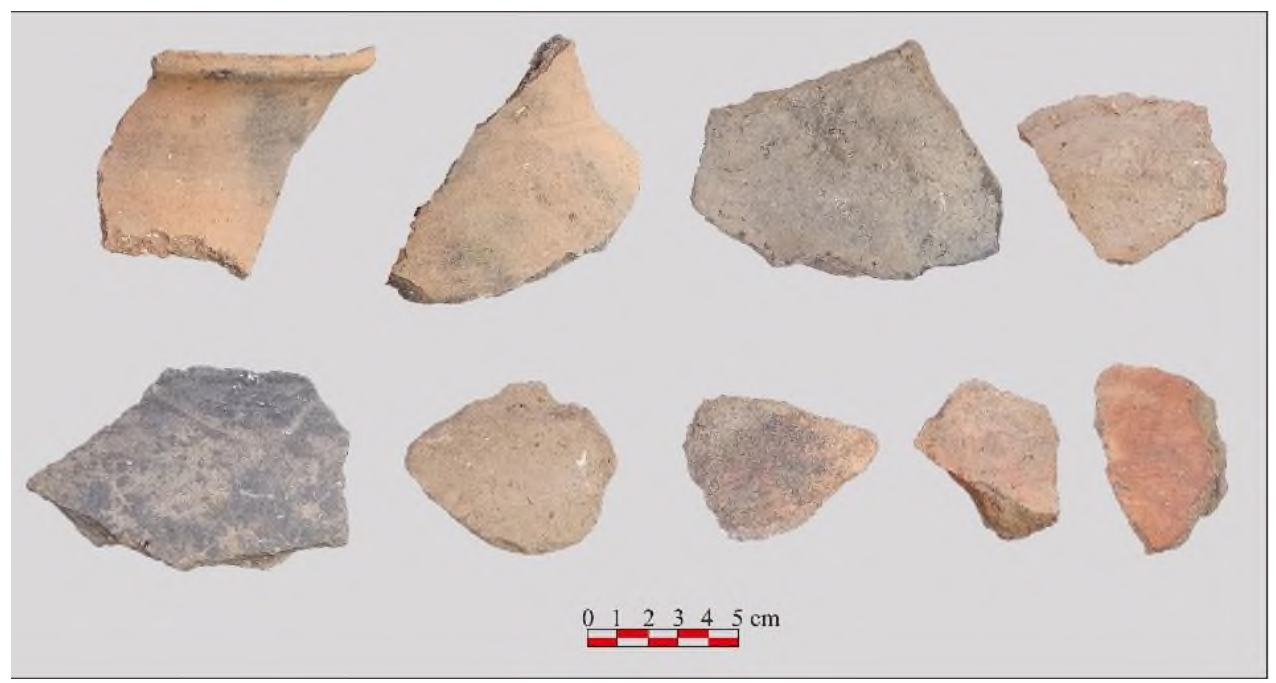

Resim 11. Balçeşme-Şipşirik Kulesi çanak-çömlek buluntuları. 
Ardahan'ın Göle İlçesindeki Demir Çağı Savunma Yapıları

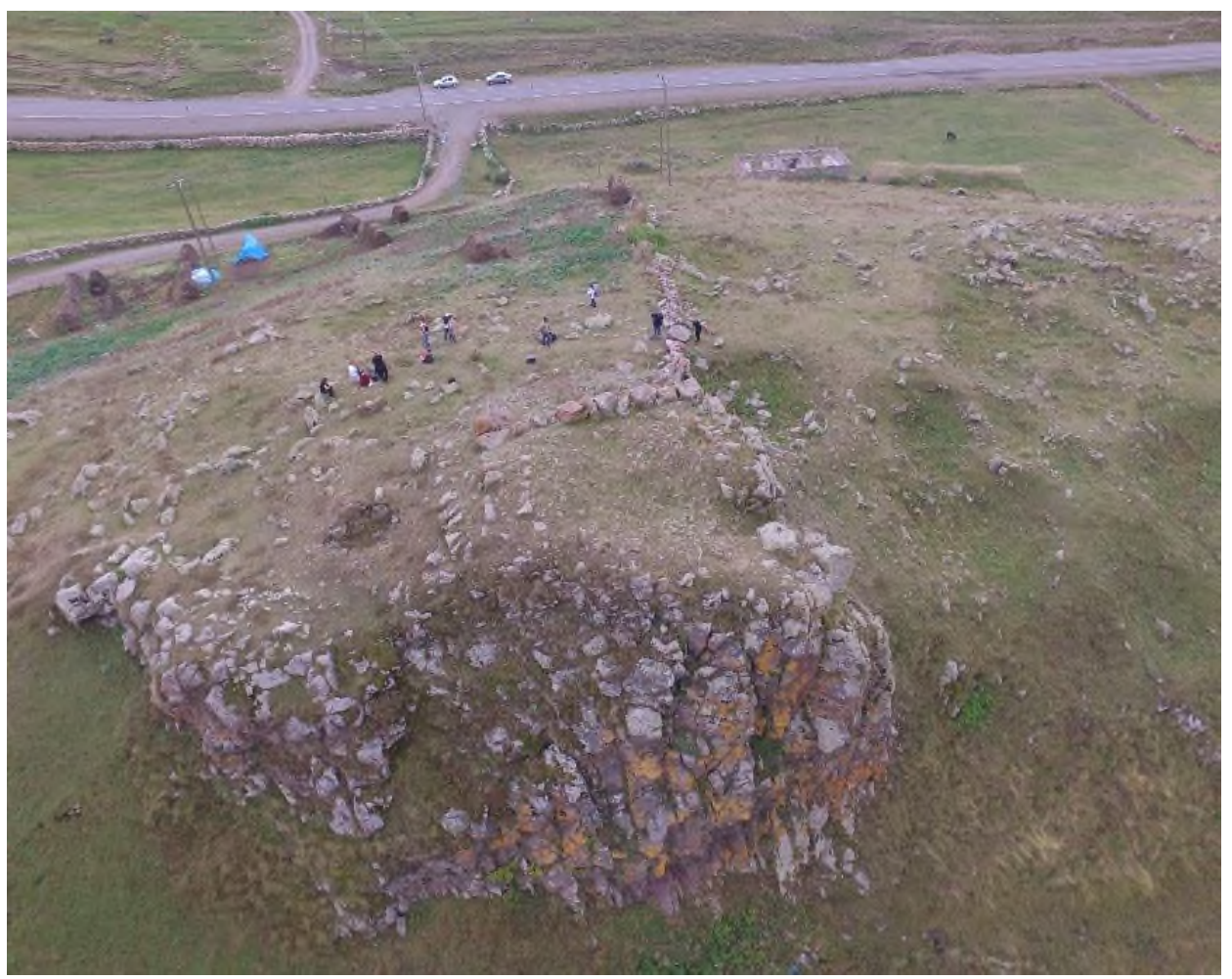




\section{Zekeriye AKKURT - Sami PATACI}

Resim 12. Balçeşme-Tekmezar Kulesi ve Yerleşimi hava fotoğrafi.

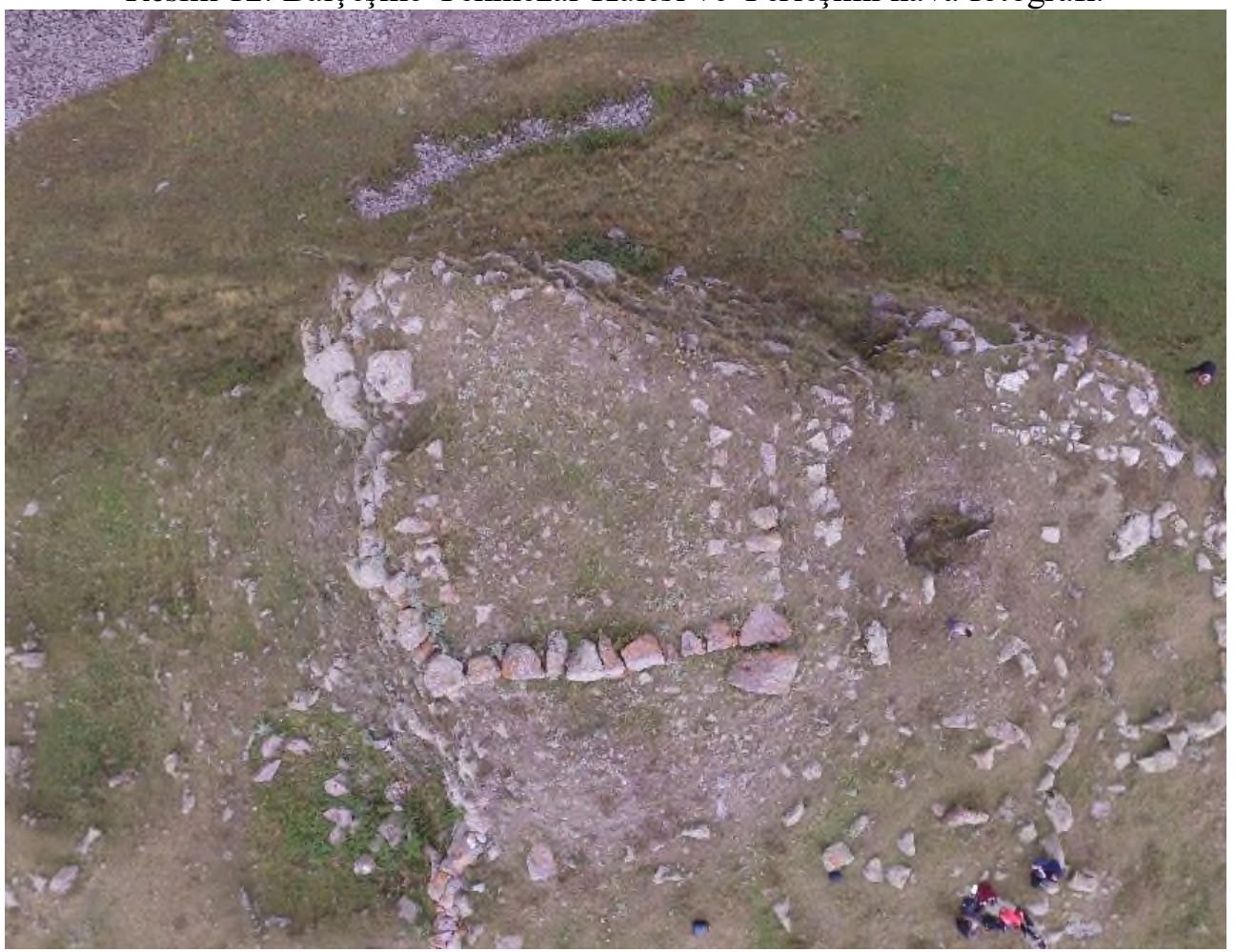

Resim 13. Balçeşme-Tekmezar Kulesinin genel yapı planı. 